\title{
Biocoatings: A new challenge for environmental biotechnology
}

\author{
Susana Cortez ${ }^{\mathrm{a}, *}$, Ana Nicolau $^{\mathrm{a}}$, Michael C. Flickinger ${ }^{\mathrm{b}}$, Manuel Mota $^{\mathrm{a}}$ \\ a Centre of Biological Engineering (CEB), University of Minho, Braga 4710-057, Portugal \\ ${ }^{\mathrm{b}}$ Golden LEAF Biomanufacturing Training and Education Center (BTEC), Department of Chemical and Biomolecular Engineering, North Carolina State \\ University, Centennial Campus, Campus Box 7928, Raleigh, NC 27695-7928, USA
}

\section{A R T I C L E I N F O}

\section{Article history:}

Received 7 September 2016

Received in revised form 8 December 2016

Accepted 16 January 2017

Available online 19 January 2017

\section{Keywords:}

Biocatalysis

Environmental biotechnology

Nanoporous latex coating

Non-growing cells

\begin{abstract}
A B S T R A C T
Adhesive biocatalytic coatings (biocoatings) have a nanoporous microstructure generated by partially coalesced waterborne polymer particles that entrap highly concentrated living cells in a dry state stabilized by carbohydrate osmo-protectants. Biocoatings can be deposited by high speed coating technologies, aerosol delivery or ink-jet printed in multilayered, patterned coatings on flexible nonporous or nonwoven substrates, preserving $10^{10}-10^{12}$ non-growing viable microorganisms per $\mathrm{m}^{2}$ in $2-50 \mu \mathrm{m}$ thick layers. Cells are rehydrated to restore their metabolism. The layers reactive half-life following rehydration can be $1000 \mathrm{~s}$ of hours. The planar structure of biocoatings enable uniform illumination of a high concentration of photo-reactive microorganisms or algae and contact these microbe with thin liquid films for efficient mass transfer. This review highlights recent advances in biocoating technology for pollutants degradation, photo-reactive coatings, stabilization of hyperthermophiles for biocatalysis, environmental biosensors, and biocomposite fuel cells. Engineering cells for desiccation tolerance, unveiling the metabolism of nongrowing cells, and engineering the interaction between the cell surface and adhesive polymer binders are fundamental challenges to open the door to vast future applications of biocoatings for environmental sensing and remediation.
\end{abstract}

(c) 2017 Elsevier B.V. All rights reserved.

\section{Contents}

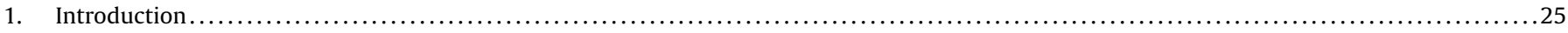

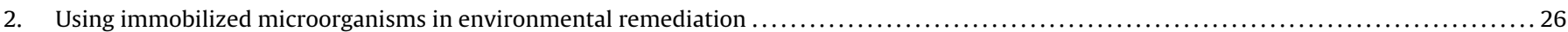

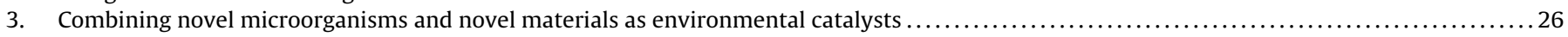

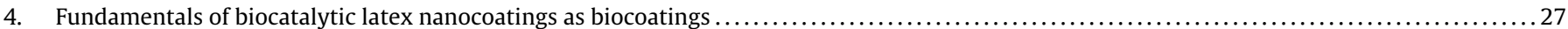

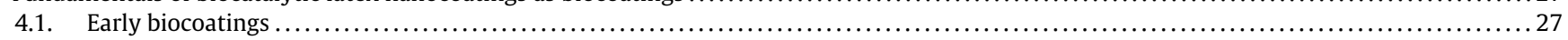

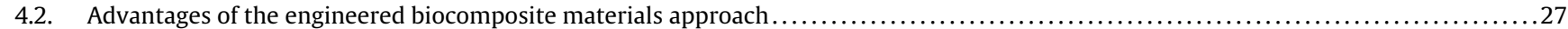

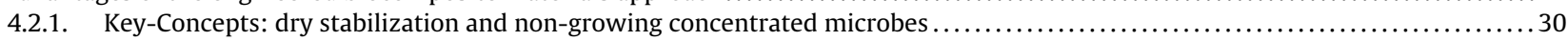

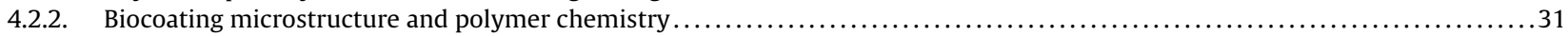

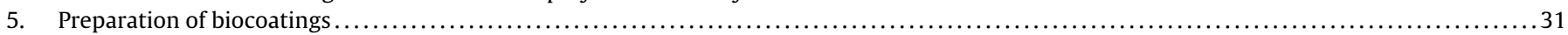

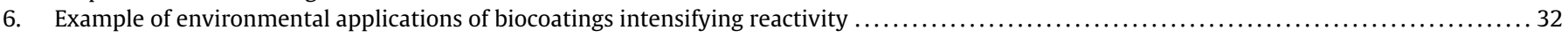

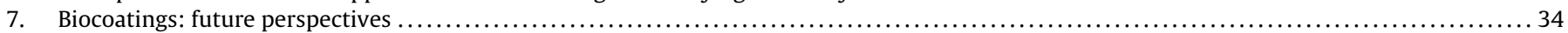

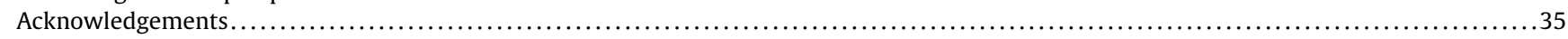

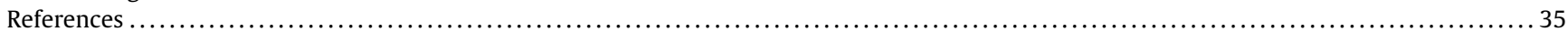

* Corresponding author. Postal address: Centre of Biological Engineering (CEB), University of Minho, Campus de Gualtar, Braga 4710-057, Portugal.

E-mail addresses: susana_cortez@deb.uminho.pt (S. Cortez), protozoa@deb.uminho.pt (A. Nicolau), mcflicki@ncsu.edu (M.C. Flickinger), mmota@deb.uminho.pt (M. Mota).

\section{Introduction}

Biotechnology will play a major role to significantly reduce energy misuse, to stop pollution, recycle gaseous carbon emissions, and reduce global warming. This has led to a search for new composite materials which concentrate (intensify) and stabilize microbes as environmental biocatalysts for rapid degradation 
of pollutants, solar energy harvesting, carbon recycling or gascleaning [1,2].

This review discusses the recent advances in fabrication methods of biocoatings - nanoporous adhesive composite materials containing highly concentrated living cells - and their potential environmental use. Biocoatings intensify catalytic conversion rates for sensing/degradation of pollutants or solar energy harvesting by highly concentrated dry-stabilized whole cells immobilized in robust adhesive latex polymer coatings or coated/entrapped within flexible nonwoven materials.

\section{Using immobilized microorganisms in environmental remediation}

Attractive features of whole cells as environmental biocatalysts compared to inorganic catalysts include versatility, high selectivity and temperature and pressure requirements that are close to environmental conditions [3,4]. However, the handling of growing microbes in large volumes of liquid media to process polluted air and wastewaters presents severe drawbacks, such as uncontrolled cell density, growth toxicity of pollutants and products, nutritional limitations and difficulties in recovering products. A physical separation from the liquid phase by immobilization of the microbes is highly advantageous, preserving high cell densities (without leaching) to intensify reactivity, significantly improving pollutant absorption/reaction rates and increasing volumetric productivity [5]. Moreover, immobilized whole cells reduce environmental catalyst cost and simplify downstream processing of products such as recycling of carbon - containing pollutants as chemicals and fuels $[6,7]$.

The use of whole living cells, either in suspension or immobilized in hydrogel beads, is well-established in industrial biotechnology $[8,9]$. Whole cells act as microbioreactors with the ability to synthesize all necessary enzymes and cofactors $[6,10,11]$. Some whole cell biocatalysts can be stabilized with minimum preparation, e.g., adsorption onto an insoluble support, hydrogel entrapment with cross linking, as natural biofilms, simple drying, or lyophilization. All these methods reduce expensive enzyme purification $[6,7,12]$. Immobilized cells may be used in a growing or non-growing state [13] or even as metabolically inactive cells [14]. The support matrix of natural biofilms and hydrogels often results in severe mass transfer limitations for diffusion of substrates to the cells and of cellular products into the bulk liquid. Embedding living cells in thin (2-50 $\mu \mathrm{m}$ thick) nanoporous adhesive coatings can significantly reduce diffusion limitations. Growing cells produce unwanted cell biomass, leading to severe mass transfer limitations and reactor plugging, and might have limited stability with organic solvents and high concentrations of pollutants or products $[6,8,15,16]$. In contrast, non-growing cells are biocatalytically active, can withstand higher concentrations of toxic pollutants (no growth inhibition), do not produce biomass as a side product and are genetically stable [13]. However, microbial physiology knowledge to engineer slow growing or non-growing cells as biocatalysts for thousands of hours of reactivity in a large-scale process is scarce $[15,17]$. Table 1 summarizes the main characteristics of microencapsulation, biofilm and biocoating processes.

\section{Combining novel microorganisms and novel materials as environmental catalysts}

An important aspect to consider in engineering immobilized whole cell biocatalysis is the material properties of the immobilization matrix [10]. Engineering polymeric immobilization matrixes will have superior wet adhesion, controlled porosity, and the ability to stabilize living cells when dried, which are not proper- ties of natural biofilms or hydrogels. Nanostructured materials in the form of nanoparticles, nanotubes, nanofibers and nanoporous matrixes are advanced materials [18] as they have unique physical and chemical properties such as large surface area to volume ratios or high interfacial reactivity [19]. One of the major advantages of incorporating advanced nano-structured materials with microorganisms in composites is that their properties can be tailored for controlling both the physical properties of the composite (microstructure, adhesion, porosity, mechanical strength) and the chemical environment immediately surrounding living cells, and thus stabilize the cells' reactivity [20]. An ideal adhesive polymer immobilization matrix should be non-toxic, non-polluting, inexpensive, functional at ambient temperature, adhesive when wet, flexible, lightweight, mechanically and chemically stabile. In addition, the choice of a proper composite support material must take into account the capacity for retention of highly concentrated cells of different shapes and volume, and the porosity to allow diffusion of nutrients, oxygen, substrates and products. A simple cost effective scalable fabrication procedure preferably using mature manufacturing technologies such as high speed latex binder paper coating and waterborne coating synthesis methods is an advantage [21-23]. Other criteria such as hydrophobic/hydrophilic balance, optical and/or electronic properties and chemical functionalities (i.e. solvation, wettability, etc.) are largely dependent on applications [24] (Table 2).

Traditional microbe immobilization supports used to entrap living cells include hydrogels, natural polysaccharides (e.g. agar, carrageenan, alginate and chitosan), proteins (e.g. gelatin, collagen, albumin) and synthetic polymers (e.g. polystyrene, polyacrylamide, polyethylene glycol, polyvinylchloride, polyurethane). Inorganic supports used for cell adsorption may be porous glass, ceramics, clay, activated charcoal, zeolite, kieselgur, diatomaceous earth, or loofa sponges [21,46]. Polymer hydrogels are not adhesive, collapse on drying and are often hundreds of microns to millimeters thick, and can have severe mass transfer limitations [13,47]. These matrixes cannot be stored dry or frozen for prolonged periods of time without loss of cell viability. Also, when hydrogel-entrapped microorganisms are incubated with nutrients to sustain cell viability and regenerate activity, significant cell release and outgrowth occur because the gel matrix is macroporous (pores larger than the entrapped microorganisms), the weak thin gel pore walls can be broken by cell growth or the cells die and are sloughed from the surface [48].

The utilization of inorganic ceramic materials for cell immobilization offer many advantages, but the harsh conditions associated with their processing are often not compatible with cell viability [48]. Some inorganic sol-gels can be processed at room temperature under mild conditions $[5,48,49]$. Furthermore, the porous nature of the sol-gel network allows easy access to external substrates or pollutants [50]. Other attractive characteristics include rigidity (silica or oxide ceramics), chemical inertness, high photochemical and thermal stability and high optical transparency. Moreover, negligible swelling in both aqueous and organic solvents is an advantage. Premkumar et al. [51] successfully entrapped recombinant bioluminescent Escherichia coli reporter strains in sol-gel silicate and maintained viability and luminescence activity for more than three months at $4{ }^{\circ} \mathrm{C}$. The main drawbacks of sol-gel matrixes include low sensitivity and reproducibility, and unwanted changes in the chemical and biological properties of the cells due to the interactions with the inner surface of the pores [52], mainly because of the intrinsic brittleness of sol-gel materials. To overcome this, polymers (e.g., chitosan, polyhydroxyl polymers), have been coupled to sol-gel materials in the form of organic-inorganic composites, thereby limiting shrinkage during the process of sol-gel formation. Sol-gel/hydrogel hybrids combine the rigidity with the biocompatibility of hydrogels, thus avoiding sol-gel cracking and hydrogel 
Table 1

Summary of main characteristics of microencapsulation, biofilm and biocoating processes.

\begin{tabular}{|c|c|c|c|}
\hline Process & Entrapment material & Geometry & Growth \\
\hline Microencapsulation & $\begin{array}{l}\text { Exogenous } \\
\text { (non-growing) }\end{array}$ & $3-\mathrm{D}$ & Growing of cells \\
\hline Biofilm & Endogenously produced by the cells & $3-\mathrm{D}$ & Biofilm growth (both cells and material growth) \\
\hline Biocoating & $\begin{array}{l}\text { Exogenous } \\
\text { (non-growing) }\end{array}$ & $2-\mathrm{D}$ & Neither cells nor material growth \\
\hline
\end{tabular}

swelling, as well as cell leaching [53]. To combine the merits of solgel and a variant of polyvinyl acetate hydrogel, Jia et al. blended both materials with a mixed culture of Thrichosporon cutaneum and Bacillus subtilis, on the surface of an oxygen probe [54]. This biochemical oxygen demand sensor retained activity and sensitivity for 40 days and could be stored for three months at $4{ }^{\circ} \mathrm{C}$ while keeping $80 \%$ of its initial activity.

Immobilized whole cell biocatalysts mimic natural biofilms which have been successfully applied in bioremediation in wastewater and exhaust gases [55]. The disadvantages of natural biofilms are time-dependent biological activity, limited control of cell concentration, limited control of film thickness, complex structure (channels) and uncontrolled cell adhesion/release (sloughing). The microbes in biofilms produce their own extracellular carbohydrate polymer immobilization matrix and are adapted to grow within the matrix [56]. Natural biofilms are inexpensive and can have long-term activity (months to years) and enhanced tolerance to toxic reactants. These characteristics can overcome limited structural stability (sloughing) and control of porosity for wastewater treatment applications [55].

\section{Fundamentals of biocatalytic latex nanocoatings as biocoatings}

\subsection{Early biocoatings}

Different terms are used in the literature to describe biocoatings: biocatalytic latex nanocoatings, biocatalytic coatings, microbial paints and inks, latex copolymer films, synthetic biofilms, biomimetic leaves, cellular composite coatings and nanobiocomposites. A biocoating consists of one or more thin layers of metabolically active microorganisms entrapped between partially coalesced adhesive insoluble latex or non-film forming polymer particles [57]. According to Mota et al. [58-60] and Lyngberg et al. [61], the ratio between the size of the partially coalesced polymer particles and the size of the cells as well as the volume ratio of each particle type are critical to the biocoating microstructure, adhesion and porosity (Fig. 1). Indeed, the porosity first decreases with the volume ratio and, at a certain point (around 70\%) it reaches a minimum from where it starts increasing. Biocoatings can be deposited on a wide variety of inexpensive and flexible materials such as polyester sheets, metals or porous materials - wood, paper, fibers, yarns and other nonwoven materials [34].

Lawton, Bunning and Flanagan [62-64] were the first to entrap living cells within latex coatings describing the immobilization of fungi, yeast and bacteria in polydispersed acrylate/vinyl acetate copolymers (particle size $\sim 260 \mathrm{~nm}$, glass transition temperature $\left.\left(\mathrm{T}_{\mathrm{g}}\right) 13^{\circ} \mathrm{C}\right)$. Coating porosity was generated by integrating calcium carbonate that was later leached with acid to form large pores for colonization by microbial growth. Cantwell et al. [65] used bimodal blends of hard and soft polymer particles ( $T_{g}$ range of -60 to $60^{\circ} \mathrm{C}$ ) to immobilize microbial cells. However, these cells were not layered in thin coatings, but only in the form of flocculates, 1-2 mm aggregates, and $2 \mathrm{~mm}$ diameter fibrils. No data was presented on cell viability following entrapment or aggregate permeability. Martens et al. [66] immobilized Synechococcus on a carbon electrode using a film-forming emulsion of methylmethacrylate and butyl acrylate copolymer. The device showed cell viability of "nearly 100\%" with photoreactivity after rehydration and illumination. The major difficulties of these early biocoating investigations, however, were low coating porosity, weak mechanical stability (delaminating from the support particles, creep), poor control of coating thickness, lack of uniformity, loss of reactivity, lack of defined coating microstructure (porosity, pore structure) and lack of cell viability data [67].

Swope and Flickinger [68] used Mayer rod drawdown coating methods with nontoxic acrylate/vinyl acetate copolymer latex binders without biocides to immobilize $E$. coli cell pastes in biocoatings of $<80 \mu \mathrm{m}$ thickness as a two-layered coating in which the bottom layer (cell coat) consisted of a mixture of cells, latex and glycerol and the top layer (topcoat) consisted of a mixture of latex and glycerol. The top nanoporous layer sealed the cells in the bottom layer (a sterile barrier). Glycerol was added as an osmoprotectant and to retard particle deformation, compaction and coalescence [69], resulting in enhanced cell viability following rehydration. Differential viability staining and laser scanning confocal microscopy (LSCM) techniques adapted from methods used to characterize natural biofilms were used to determine the viability of the entrapped $E$. coli, which was $\sim 95 \%$ for several weeks following rehydraton. However, LSCM to determine cell viability has limited penetration into the coatings due to photobleaching [68]. Subsequent work by Lyngberg et al. [57] using E. coli coatings showed that the addition of sucrose plus glycerol combined with controlled drying and controlling the ratio of cell size to polymer particle size could increase coating porosity and eliminate coat blistering during drying and rehydration. In addition to acting as porogens, carbohydrates such as sucrose or trehalose added to the latex formulation impart desiccation tolerance to the entrapped cells. During ambient drying, the coatings dry due to a glass transition resulting in vitrification of extra- and intracellular carbohydrates and ions, which form stabilizing complexes around and within the cells. Subsequently, a simple pressure sensitive vinyl mask method was developed which eliminated coating edge effects - loss of cells from the coating edge following rehydration [70]. Multilayer patch coatings of $12.5 \mathrm{~mm}$ to $35 \mathrm{~mm}$ in diameter were fabricated from 5 to $65 \mu \mathrm{m}$ thick using these drawdown methods [70]. These studies established methods to generate thin adhesive latex patch coatings ( $\sim 2$ to $\sim 75 \mu \mathrm{m}$ thick) two orders of magnitude thinner than cross-linked hydrogels and most natural biofilms used for bioremediation, and to control latex coating porosity formed during ambient drying. These investigations also established that latex coatings maintained their adhesive properties and integrity when rehydrated for cell concentrations as high as $50 \%$ of coating volume.

\subsection{Advantages of the engineered biocomposite materials approach}

Biocoatings entrapping highly concentrated cell pastes stabilize viable but non-growing microorganisms in thin $(2-<50 \mu \mathrm{m})$, adhesive, nanoporous, partially-coalesced, insoluble polymer coatings with minimal diffusion resistance $[57,70]$. Colloid-based latex 


\begin{tabular}{|c|c|c|c|}
\hline Microorganism & Host support & $\begin{array}{l}\text { Purpose of } \\
\text { immobilization }\end{array}$ & Comments \\
\hline $\begin{array}{l}\text { Escherichia coli, } \\
\text { Saccharomyces } \\
\text { cerevisiae }\end{array}$ & $\begin{array}{l}\text { Mixture of } 0.5 \% \\
\text { agarose, } 1 \% \\
\text { polyvinylpyrrolidone } \\
\text { and } 0.05 \% \text { collagen }\end{array}$ & $\begin{array}{l}\text { Biosensor for copper } \\
\text { ion detection }\end{array}$ & $-80 \%$ of cell viability after 1 month (storage at $4{ }^{\circ} \mathrm{C}$ ) \\
\hline Pseudomonas species & Polyvinyl alcohol & $\begin{array}{l}\text { Degradation of phthalic } \\
\text { acid esters }\end{array}$ & $\begin{array}{l}\text {-the degradation rate of immobilized cells was higher than free cells; } \\
\text {-the immobilization of microbial cells did not change their original metabolic pathway }\end{array}$ \\
\hline Chlorella sorokiniana & Loofa sponge & $\begin{array}{l}\text { Nickel (II) } \\
\text { accumulation }\end{array}$ & -immobilized cells accumulated $25 \%$ more nickel than free cells after 20 min of exposition \\
\hline Spirulina platensis & $\begin{array}{l}\text {-Alginate } \\
\text {-Silica }\end{array}$ & $\begin{array}{l}\text { Cadmium } \\
\text { accumulation }\end{array}$ & $\begin{array}{l}\text {-the maximum biosorption capacities for alginate immobilized cells and silica immobilized } \\
\text { cells were } 70.92 \text { and } 36.63 \mathrm{mg} \mathrm{Cd} \mathrm{g}^{-1} \text { biomass, respectively (high cadmium sorption capacity); } \\
\text {-the immobilized cells could be repeatedly used in the sorption process up to five times }\end{array}$ \\
\hline $\begin{array}{l}\text { Genetically modified } \\
\text { Escherichia coli }\end{array}$ & Silica sol-gel & Degradation of atrazine & $\begin{array}{l}\text {-at room temperature, the encapsulated non-viable cells maintained a specific activity } \\
\text { between } 0.44 \pm 0.06 \text { and } 0.66 \pm 0.12 \mu \mathrm{mol} \mathrm{g}^{-1} \mathrm{~min}^{-1} \text { for up to } 4 \text { months, comparing with free, } \\
\text { viable cell-specific activities }\left(0.61 \pm 0.04 \mu \mathrm{mol} \mathrm{g}^{-1} \mathrm{~min}^{-1}\right) \text {; } \\
\text {-when encapsulated, non-viable cells were assayed at } 4^{\circ} \mathrm{C} \text {, the activity increased threefold } \\
\text { over free cells }\end{array}$ \\
\hline Mucor circinelloides & Polyurethane foam & $\begin{array}{l}\text { Recovery of omega-3 } \\
\text { from fish oil waste }\end{array}$ & $\begin{array}{l}\text {-the optimum hydrolysis products were obtained at } \mathrm{pH} 7 \text { and } 35^{\circ} \mathrm{C} \text {; } \\
\text {-a } 12.6 \% \text { increase of omega- } 3 \text { concentration in comparison to initial omega- } 3 \text { concentration in } \\
\text { the crude fish oil waste was observed }\end{array}$ \\
\hline Bacillus sphaericus & Silica sol-gel & $\begin{array}{l}\text { Copper and uranium } \\
\text { accumulation }\end{array}$ & -the immobilized cells accumulated more pollutants than matrixes with spores or S-layers \\
\hline $\begin{array}{l}\text { Rhodopseudomonas } \\
\text { palustris }\end{array}$ & $\begin{array}{l}\text { Biocide-free } \\
\text { polyvinylacetate-co- } \\
\text { acrylate copolymer } \\
\text { latex }\end{array}$ & Hydrogen production & $\begin{array}{l}\text {-the immobilized cells were more reactive than an equivalent number of suspended or settled } \\
\text { cells and remained active after hydrated storage for greater than } 3 \text { months in the dark and } \\
1 \text { year when stored at }-80^{\circ} \mathrm{C}\end{array}$ \\
\hline $\begin{array}{l}\text { Synechococcus } \\
\text { PCC7002, Synechocystis } \\
\text { PCC6803, Synechocystis } \\
\text { PCC6803, and Anabaena } \\
\text { PCC7120 }\end{array}$ & $\begin{array}{l}\text { Solvent-free acrylate } \\
\text { copolymer latex binder }\end{array}$ & Photosynthesis & $\begin{array}{l}\text {-the immobilized cells intensified up to } 10 \text {-fold the specific photoreactivity of suspended cells } \\
\text { in non-growth media designed from photosynthetic quotient data }\end{array}$ \\
\hline $\begin{array}{l}\text { Rhodotorula } \\
\text { mucilaginosa }\end{array}$ & Sugarcane bagasse & Biodiesel production & $\begin{array}{l}\text {-the maximum biodiesel yield was obtained at } 85.29 \% \text { with the optimum conditions of } 1.5 \mathrm{~g} \\
\text { whole cell biocatalyst, } 1: 12 \text { methyl acetate to oil ratio, } 10 \% \text { water content }(\mathrm{w} / \mathrm{w}) \text {, temperature } \\
\text { of } 40^{\circ} \mathrm{C}, 60 \mathrm{~h} \text { of reaction time and agitation at } 250 \mathrm{rpm} \text {; } \\
\text {-the stability of immobilized whole cell biocatalyst was studied with } 10 \text { cycles of repeated } \\
\text { usage and it was shown that there was no significant loss of lipase activity in the presence of } \\
\text { methyl acetate. }\end{array}$ \\
\hline $\begin{array}{l}\text { Genetically modified } \\
\text { Escherichia coli }\end{array}$ & $\begin{array}{l}\text { Mussel adhesive } \\
\text { protein (MAP) }\end{array}$ & $\begin{array}{l}\text { Biosensor for } \\
\text { organophosphate } \\
\text { compounds detection }\end{array}$ & $\begin{array}{l}\text {-the whole cell array biosensor system, prepared using optimal MAP coating }\left(50 \mathrm{mg} \mathrm{cm}^{2}\right) \text { and } \\
\text { cell loading }\left(4 \mathrm{OD}_{600}\right) \text {, detected paraoxon levels as low as } 5 \mathrm{mM} \text { with high reproducibility, and } \\
\text { its quantitative detection range was } 5-320 \mathrm{mM} \text {; } \\
\text {-the tested biosensor showed a good long-term stability for } 28 \text { day with } 80 \% \text { retained activity } \\
\text { and a reusability of up to } 20 \text { times; } \\
\text {-paraoxon in tap water was also successfully detected without a reduction in sensitivity }\end{array}$ \\
\hline Rhizopus oryzae & $\begin{array}{l}\text { Rigid polyethylene } \\
\text { biomass support }\end{array}$ & Biodiesel production & $\begin{array}{l}\text {-supplementation of the medium with carbon sources led to higher lipase activity and } \\
\text { increased the biomass immobilized on the support; } \\
\text {-a cultivation period of } 72 \mathrm{~h} \text { in a basal medium supplemented with both cottonseed oil and } \\
\text { glucose is optimal for biodiesel production by } R \text {. oryzae, resulting in a fatty acid methyl ester } \\
\text { yield of } 27.9 \mathrm{wt} \%\left(228.2 \mathrm{~g} \mathrm{~L}^{-1}\right)\end{array}$ \\
\hline
\end{tabular}
yield of $27.9 \mathrm{wt} \%\left(228.2 \mathrm{~g} \mathrm{~L}^{-1}\right)$ 
Table 2 (Continued)

\begin{tabular}{|c|c|c|c|c|}
\hline Microorganism & Host support & $\begin{array}{l}\text { Purpose of } \\
\text { immobilization }\end{array}$ & Comments & Refs. \\
\hline $\begin{array}{l}\text { Genetically modified } \\
\text { Escherichia coli }\end{array}$ & Calcium alginate & $\begin{array}{l}\text { Degradation of } \\
\text { organophosphate } \\
\text { compounds }\end{array}$ & $\begin{array}{l}\text {-optimum bead loadings for bioreactor operation were found to be } 200 \mathrm{~g}^{\text {beads } \mathrm{L}^{-1} \text { for }} \\
\text { chlorferon degradation and } 300 \mathrm{~g} \text { beads } \mathrm{L}^{-1} \text { for diethlythiophosphate degradation; } \\
\text {-using waste cattle dip solution as substrate, the degradation rate for an immobilized } \\
\text { consortium of chlorferon-degrading bacteria was five times greater than that for freely } \\
\text { suspended cells, and hydrolysis of coumaphos by immobilized recombinant Escherichia coli } \\
\text { was } 2.5 \text { times greater. }\end{array}$ & [39] \\
\hline $\begin{array}{l}\text { Geobacter } \\
\text { sulfurreducens }\end{array}$ & $\begin{array}{l}\text { Pectin embedded on } \\
\text { graphite electrodes }\end{array}$ & $\begin{array}{l}\text { Electrical current } \\
\text { production (microbial } \\
\text { fuel cell) }\end{array}$ & $\begin{array}{l}\text {-immediately after immobilizing G. sulfurreducens on electrodes, electrical current was } \\
\text { obtained without addition of exogenous electron shuttles or electroactive polymers; } \\
\text {-electrodes maintained at }+0.25 \mathrm{~V} \text { initially produced } 0.52 \mathrm{~A} \mathrm{~m}^{-2} \text { in the presence of acetate as } \\
\text { the electron donor; } \\
\text {-when electrodes were maintained at an oxidizing potential for } 24 \mathrm{~h} \text {, electron transfer to } \\
\text { electrodes increased to } 1.75 \mathrm{Am}^{-2}\end{array}$ & [40] \\
\hline $\begin{array}{l}\text { Genetically modified } \\
\text { Escherichia coli }\end{array}$ & $\begin{array}{l}\text { Sodium alginate, } \\
\text { cellulose sulfate }\end{array}$ & $\begin{array}{l}\text { Preservation of cell } \\
\text { viability for long term } \\
\text { storage }\end{array}$ & $\begin{array}{l}\text {-more than } 90 \% \text { of the cell viability was preserved during the encapsulation process } \\
\text {-the initial cell activity was fully maintained within encapsulated cells while it halved in free } \\
\text { cells }\end{array}$ & [41] \\
\hline Aspergillus oryzae & $\begin{array}{l}\text { Polyurethane foam } \\
\text { cuboids }\end{array}$ & Biodiesel production & $\begin{array}{l}\text {-immobilized A. niger whole cell lipase showed biodiesel conversion of } 80.97 \% \text { and yield of } \\
90.82 \% \text { at } 35^{\circ} \mathrm{C} \text {, methanol to oil ratio of 5:1 with } 2.5 \% \text { water content based on oil weight and } 6 \\
\text { biomass support particles with step-wise methanol addition }\end{array}$ & [42] \\
\hline $\begin{array}{l}\text { Pseudomonas } \\
\text { mendocina }\end{array}$ & $\begin{array}{l}\mathrm{Fe}_{3} \mathrm{O}_{4} \text { chitosan } \\
\text { microspheres }\end{array}$ & Biodiesel production & $\begin{array}{l}\text {-a maximum biodiesel yield of } 87.32 \% \text { was obtained under the optimum operating condition } \\
\text { (magnetic whole-cell biocatalysts concentration of } 10 \mathrm{wt} . \% \text {, water content of } 10 \mathrm{wt} . \%, 35^{\circ} \mathrm{C} \text {, } \\
\text { methanol to oil molar ratio of } 4: 1 \text { and a four-step addition of methanol) for } 48 \mathrm{~h} \text {; } \\
\text {-magnetic whole-cell biocatalysts still gave a biodiesel yield of } 83.57 \% \text { after } 10 \text { cycles, which } \\
\text { was higher than that of } \mathrm{Fe}_{3} \mathrm{O}_{4} \text { - uncontained whole cell biocatalysts ( } 74.06 \% \text { ) }\end{array}$ & [43] \\
\hline Bacillus fusiformis & $\begin{array}{l}\text { Alginate-polyvinyl } \\
\text { alcohol (PVA)-clays }\end{array}$ & $\begin{array}{l}\text { Degradation of } \\
\text { naphthalene }\end{array}$ & $\begin{array}{l}\text {-more than } 99.7 \% \text { of naphthalene was removed within } 12 \mathrm{~h} \text {, containing bentonite } 2 \%(\mathrm{w} / \mathrm{v}) \text {, } \\
\text { PVA } 12 \%(\mathrm{w} / \mathrm{v}) \text {, alginate } 0.3 \%(\mathrm{w} / \mathrm{v}) \text { and } 10 \%(\mathrm{v} / \mathrm{v}) \text { initial biomass loading; } \\
\text {-immobilized cells remained stable after storage at } 4{ }^{\circ} \mathrm{C} \text { for } 35 \text { days and being reused } 8 \text { times } \\
\text { ( } 12 \text { days); } \\
\text {-the naphthalene degradation rate of immobilized cells was maintained }(94.3 \%) \text { at the eighth } \\
\text { cycle }\end{array}$ & [44] \\
\hline Ganoderma lucidum & $\begin{array}{l}\text { Ca-alginate }(\mathrm{Ca}) / \text { poly- } \\
\epsilon \text {-caprolactone } \\
(\mathrm{PCL}) / \text { corn-cobs beads }\end{array}$ & $\begin{array}{l}\text { Remediation of } \\
\text { anthracene (ANT) }\end{array}$ & $\begin{array}{l}\text {-removal of ANT reached } 96.2 \% 2 \% \text { from soil after } 20 \text { days of incubation at pH } 5.0 \text { and } 45^{\circ} \mathrm{C} \\
\text { with an optimum PCL concentration in CA/PCL/corn-cobs beads of } 12 \%\end{array}$ & [45] \\
\hline
\end{tabular}



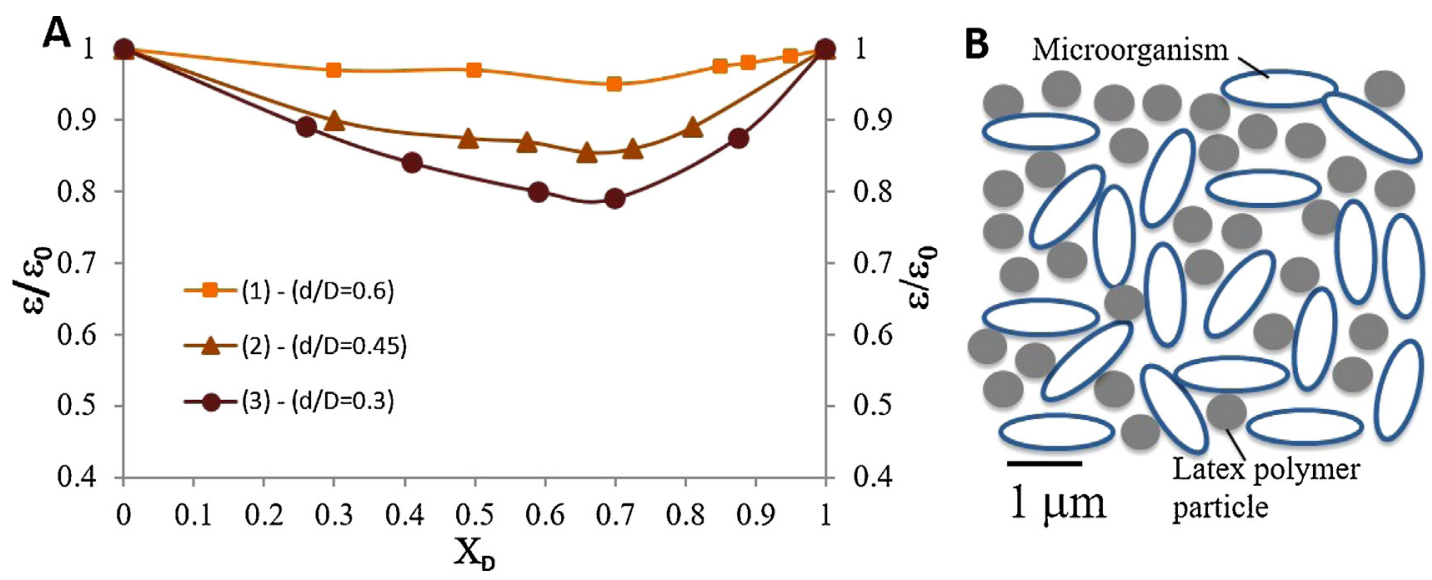

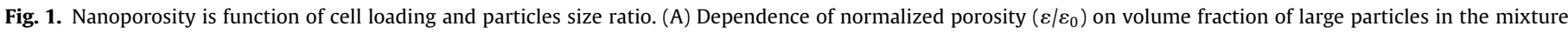

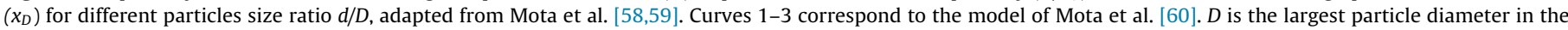

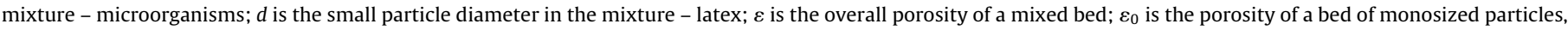
$\varepsilon_{0}=0.407$. (B) Microorganisms with approximately the triple size of polymer particles roughly corresponding to curve 3 .

biocomposite adhesives can stabilize desiccated vegetative cells without loss of reactivity, concentrate cells (500-1000-fold) to a very high volume fraction ( $>50 \%$ by weight depending on cell size), and incorporate carbohydrate osmoprotectants to maintain the integrity of microbial membranes during controlled ambient drying $[47,67,71]$. After rehydration, these cellular composites were shown to be capable of new protein synthesis without outgrowth for thousands of hours [13].

This technology is based on biocide-free waterborne latex binder emulsions. Latex paint binder emulsions are low cost materials $\left(\sim \$ 1 \mathrm{~m}^{-2}\right)[72]$ and can be formulated to protect the embedded cells from UV damage [13]. Latexes can be applied using high speed industrial coating and printing methods and offer great flexibility in the design of polymers for engineered porosity, adhesion (particularly wet adhesion) and lack of toxicity [73]. Polymer heterogeneity that contributes to film morphology and adhesion after drying in latex coatings is well studied by the waterborne coating industry $[74,75]$. However, the complex molecular interactions between heterogeneous polymer particle surface chemistry, water, surfactants, viscosity modifiers, osmoprotectant carbohydrate, and the complex surface of living cells during film formation and drying is only beginning to be explored by polymer emulsion chemists in order to alter coating functionality using biotechnology [76]. Furthermore, since carbohydrates such as sorbitol protect biological material, it is anticipated their application on coating mixture in order to increase long-term stabilization and preservation of many types of cells and biological materials in biocoatings.

\subsubsection{Key-Concepts: dry stabilization and non-growing concentrated microbes}

The real advantage of combining advanced colloid and adhesive polymer materials with microbes lies in the dry-stabilization of concentrated microbes that do not grow out from the microstructure nano-pores (pores smaller than the microbes). This enables the cells to remain catalytically active for thousands of hours with comparable half-lives to chemical catalysts.

Most bioprocesses catalyzed by microbes continuously generate biomass as the bacteria grow and multiply by consuming reactants meant for conversion to a desired product. This wasteful use of reactants can be avoided by keeping the bacteria in a non-growing but active state. This concept is particularly important for large-scale environmental processes such as anaerobic digestion where the production of excessive biomass is not desirable. It is also important for overall process efficiency as defined by the efficiency factor $\mathrm{E}$ - the ratio of waste products produced divided by products. $\mathrm{E}$ must be very low $(\sim 0.1)$ for large volume catalysis $[77,78]$. New cell biomass is a waste product that significantly increases $\mathrm{E}$.

For example, non-growing cells can be used as whole-cell biocatalysts for microbial production of hydrogen gas $\left(\mathrm{H}_{2}\right)$. Photoheterotrophic bacteria usually exhibit high $\mathrm{H}_{2}$ yields when utilizing organic substrates, although their $\mathrm{H}_{2}$ production rate is low [79]. In contrast, fermentative $\mathrm{H}_{2}$ production by strict and/or facultative anaerobes proceeds at a fast rate but with a low $\mathrm{H}_{2}$ yield. Gosse et al. [33] and Ishikawa et al. [80] studied immobilized Rhodopseudomonas palustris and immobilized E. coli, respectively (facultative bacteria); and reported continuous $\mathrm{H}_{2}$ production was possible as long as acetate or glucose was replenished periodically. Seol et al. [81] evaluated the $\mathrm{H}_{2}$ production activity of four Enterobacteriaceae strains, under growing and non-growing conditions, using glucose or formate as the carbon source and concluded that formate was much better substrate than glucose for $\mathrm{H}_{2}$ production. Gosse et al. [13] reported hydrogen gas evolution at a constant rate for over $4000 \mathrm{~h}$ using a submerged biocomposite latex coating of $R$. palustris on polyester sheet without outgrowth. In order to better understand metabolic activities of non-growing cells, and improve engineered biocatalysts, McKinlay et al. [15] tracked changes in biomass composition and global transcript levels of Rhodopseudomonas palustris when starved for nitrogen. They observed that during starvation $R$. palustris diverted their metabolism from biosynthesis to mobilize electrons for $\mathrm{H}_{2}$ production, resulting in a 3.5-fold enhancement of hydrogen gas evolution without cell division. This emphasizes that several approaches may achieve non-growth, e.g., nutritional conditions, temperature, process conditions, or genetic methodologies, to optimize the performance of biocoatings.

Biocoatings also depend on cell desiccation tolerance. Changes in the mobility of water and solvents may be the mechanism of stabilization of living cells in nanoporous coatings resulting from increasing fluid viscosity and entropic confinement during film formation and simultaneous pore formation by arrested polymer particle coalescence [67]. Common methods of dry-preservation of live cultures include freezing in glycerol and freeze-drying. Numerous microorganisms, insect larvae and insects known as anhydrobiotes are able to survive with almost complete loss of "free" body water to levels of $0.5-0.01 \mathrm{~g}$ water/gram cell dry weight. The dry organisms may remain in a state of anhydrobiosis, for decades without apparent damage. When water again becomes available, they rapidly rehydrate and resume their normal metabolic functions [82]. Anhydrobiosis depends on a series of complex physiological adaptations which are important 
in protecting anhydrobiotes from desiccation damage, including up-regulation of highly hydrophilic proteins and production of intracellular non-reducing disaccharides such as trehalose. Despite the discovery of various mechanisms involved in desiccation and water stress, knowledge of the regulatory network governing the stability of the cellular structures and the metabolic machinery active during dehydration by ambient drying is almost unknown [82-84].

\subsubsection{Biocoating microstructure and polymer chemistry}

Creation of thin biocoating microstructure that allows diffusion of reactants and products through the polymer matrix requires that latex particle deformation and coalescence be carefully controlled during the drying process. Choice of latex polymer, polymer particle size and distribution, control and manipulation of drying and hydration conditions, and use of additives are among the means available to achieve this goal [73]. Biocoatings generated from a mixture of cell paste and an emulsion of $\mathrm{pH}$ adjusted non-toxic adhesive (deformable) latex binder emulsions, bimodal particle blends or core shell lattices can have engineered adhesion to a wide variety of surfaces [76]. Adhesion (to substrate, layer to layer) can be altered by polymer particle glass transition temperature $\left(T_{g}\right)$, latex particle surface chemistry (charge, charge density, surface grafting of crosslinking agents), and the ratio of particle diameter to cell size and polymer particle to cell concentration in the coating emulsion (Fig. 1) [47,67]. If these porous composite coatings are strong enough, they can be stripped (delaminated) from the substrate and mounted as stand-alone films and their diffusion properties as a function of microstructure directly measured in a diffusion apparatus $[57,67]$.

Thin latex biocoatings containing carbohydrates stabilize, and preserve the integrity of microbial membranes during drying, thereby preserving cell viability [67]. Coating thickness is controlled by the deposition method, emulsion formulation (percent solids), and by the number of layers applied. Polymer particle coalescence and therefore the permeability is controlled by polymer-water interfacial tension, capillary pressure, layer compression, and interparticle adhesion [85]. Even after dried and rehydrated, reduction in the coating permeability can occur by "wet coalescence" depending on time, relative humidity and temperature for some low $\mathrm{T}_{\mathrm{g}}$ polymer particle emulsions $[67,85]$.

For optimal reactivity of entrapped cells, pores should be large enough to allow unrestricted transport of molecules including buffer ions, gases, substrates, and products but be nanopores $(<1 \mu \mathrm{m})$ to prevent leakage or outgrowth of microorganisms [86]. Nanoporosity is generated by the addition of glycerol and carbohydrates to arrest polymer particle coalescence during film formation of low $T_{g}$ emulsions. These additives also protect the entrapped cells from osmotic stress during coating formation prior to deposition [12]. However, when rehydrated, the entrapped porogens are leached and porosity can slowly be lost as a function of time and temperature as a result of wet coalescence [67]. Bimodal polymer blend [87] and core-shell approaches can minimize wet coalescence following rehydration [67]. Latexes with $\mathrm{T}_{\mathrm{g}}$ above the temperature at which biocatalysis is to be performed afford greater mechanical strength and shear resistance [73].

Biocoatings must contain a density of microorganisms below the critical concentration that would disrupt polymer particle coalescence. This is analogous to the maximum or critical pigment volume concentration (PVC) in latex paints [88]. However, the presence of high concentrations of cells can decrease porosity and block polymer particle coalescence depending on cell size and the interaction between the cell surface and the surface of the polymer particles [12]. Biocoatings with $E$. coli densities as high as $50 \%$ by volume, $2 \times 10^{11}$ cells $\mathrm{cm}^{-3}$ of coating volume, have been reported [89].
Lyngberg et al. [57] studied the diffusive permeability of rehydrated wet latex polymer only and of E. coli-containing biocoatings (delaminated from a metal substrate) as the effective diffusion coefficient $\left(D_{\text {eff }}\right.$ in $\left.\mathrm{cm}^{2} \mathrm{~s}^{-1}\right)$ corrected for coating thickness expressed as a dimensionless ratio (between 0 and 1 ) of the effective diffusivity to the diffusivity of tracers such as $\mathrm{KNO}_{3}$ or riboflavin in pure water $(D)$. This ratio is the diffusive permeability of the coating irrespective of the diffusing species. The decreasing effective diffusion coefficient as a function of increasing $E$. coli cell dry weight indicates that for a specified coating thickness, there is an optimum cell content at which the biocoating has an effective diffusion coefficient both for reactant species and nutrients high enough to sustain cell viability at the innermost cell layers [67].

\section{Preparation of biocoatings}

Some common biocoating deposition techniques include extrusion [34,90,91], spray drying [92], the wire wound rod drawdown Mayer rod coating method [13,67,93], 3-D ink-jet deposition [94] and the convective assembly $[12,47,95]$. Recently, dielectrophoresis (DEP) has also been used to generate photoreactive cyanobacteria cell monolayers on top of polyelectrolyte adhesives [96].

The wire wound or Mayer rod drawdown coating method (Fig. 2) was used in early biocoatings to deposit biocomposites of randomly oriented microbial cells and $\sim 150$ to $\sim 300 \mathrm{~nm}$ latex particles in $5-100 \mathrm{~cm}^{2}$-scale patches, strips, or sheets on flexible polyester substrates with a range of thicknesses from 10 to $250 \mu \mathrm{m}$, in either monolayer or multilayer biocoatings $[13,33,57,87]$. This method is capable of fabricating biocoatings of $<10 \mu \mathrm{m}$ thick [67]. Coating preparation involves a controlled coalescence/drying step and, if needed, a subsequent short-term storage period, both affected by temperature and usually carried out at 50\%-60\% relative humidity [33]. Coatings can be made in filtered air, in an anaerobic hood, or in a contained coating enclosure with both humidity and air-borne particulate control. Coating thickness can be altered by rod wire diameter, emulsion formulation (percent solids), rod pressure and mask thickness [67]. Biocoatings can be cast on non-sterile substrates (cleaned with $70 \%$ ethanol) using non-sterile biocide-free latex emulsions (adjusted to neutral $\mathrm{pH}$ ) under non-aseptic conditions [67]. The Mayer rod method relies on self-leveling low $\mathrm{T}_{g}$ acrylate co-polymer or non-film forming polymer particle blends plus carbohydrates to alter compaction and arrest coalescence during evaporation to generate nanoporosity, which can result in a mixture of particle packing configurations [13,33,47,65,87].

A continuous convective colloid assembly method (CCSA) has recently been reported to deposit whole cells and waterborne polymer particles. These particles are ordered by evaporation of the meniscus into thin $(<10 \mu \mathrm{m}$ thick), organized films with engineered adhesion, composition, thickness, and particle packing, over larger surface areas (Fig. 2) [12]. Jenkins et al. [47] found that net charge leading to repulsion between particles or between particles and $S$. cerevisiae is important in coating assembly. CCSA was used to precisely order yeast or polymer particles into closely packed monolayer coatings (one cell thick) with minimal void space. Kumnorkaew et al. [97] demonstrated that when the meniscus height is larger than the particle diameter, multilayer coatings will form [97]. The number and type of layers is easily adjusted by altering the suspension volume fraction and coating knife speed, allowing for precise control in particle packing and coating thickness [95,97,98] (Fig. 2B). Convective assembly deposition methods could lead to rapid fabrication of well-ordered arrays of cells for multi-layer systems with hybrid functionality [95]. Methods to generate cell monolayers (one cell thick adhesive biocoatings) with engineered adhesion and reactivity are the starting point for the construc- 

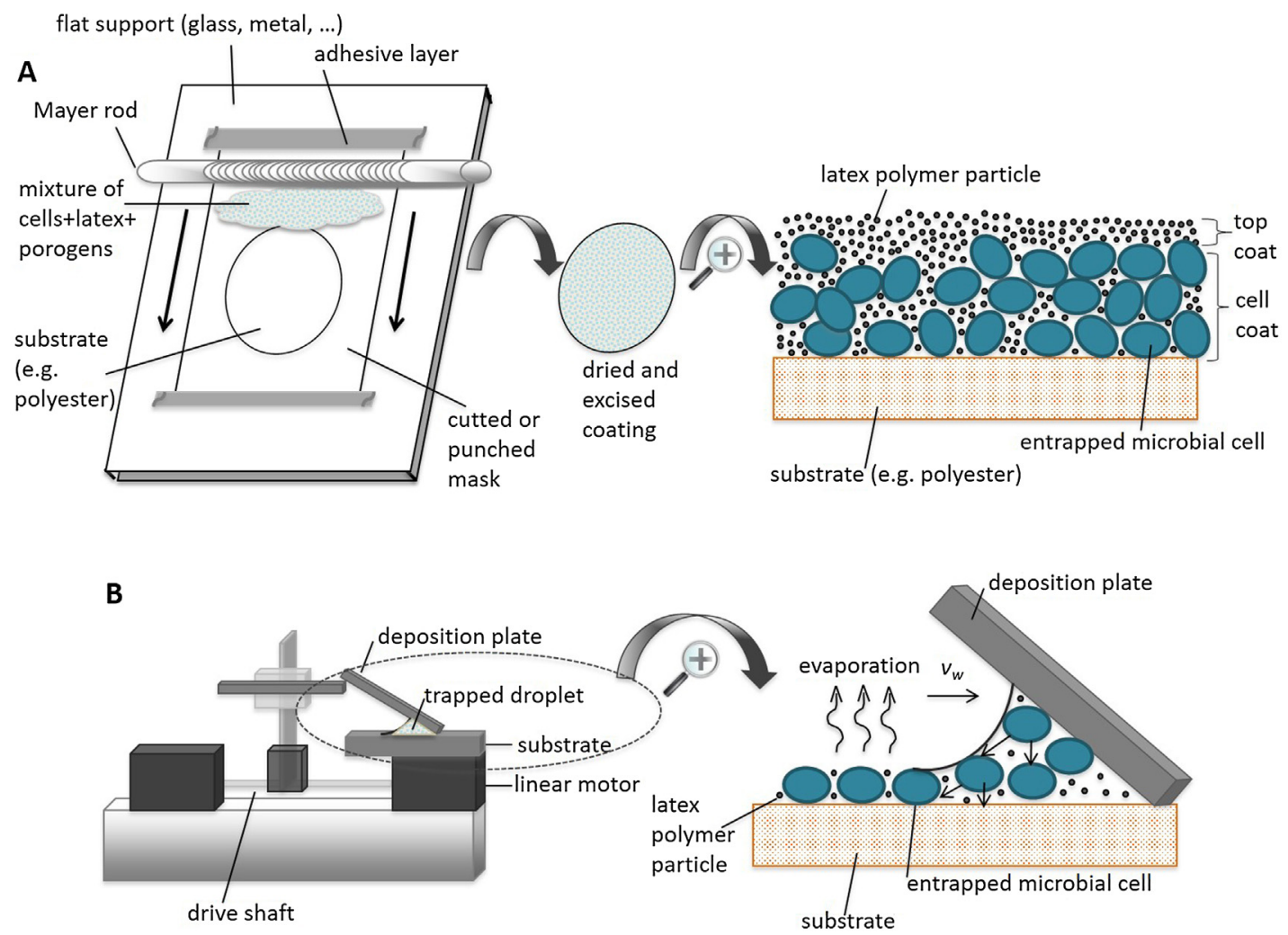

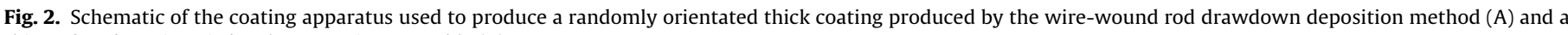
thin ordered coating via batch convective assembly (B).

tion of structured multi-layer systems [97]. Biocoatings formed from CCSA monolayers can also stabilize living cells which can add self-cleaning capabilities for releasing or digesting surface contaminants [12]. Once CCSA monolayer fabrication methods are refined, layer-by-layer (LBL) methods can be used to generate perfusive channeled systems with tailored fluid distribution, light scattering, gas harvesting and gas absorbing reactivity [13].

Many classical whole cell immobilization techniques such as hydrogels are reversible and cells can be released from their entrapment, enabling the measurement of cell number, viability and reactivity of the recovered cells. Cell recovery is not possible in most adhesive insoluble biocoatings. Nondestructive protocols to monitor bacteria directly using fluorescent reporters and confocal microscopy are available [68] similar to methods to monitor natural biofilm structure and cell viability (Fig. 3).

\section{Example of environmental applications of biocoatings intensifying reactivity}

Biocoatings are beginning to be investigated for a variety of environmental applications (Fig. 4).

Estrada et al. [99] entrapped Pseudomonas putida F1 in a nanoporous latex coating for intensification of biofilters for toluene vapors degradation. These biocoatings showed volumetric toluene mineralization rates and specific biodegradation rates 10 times higher than when using agarose biofilms. The high rates were attributed to the markedly decreased diffusional resistance in the thin biocoatings, demonstrating the intensification concept for engineering advanced biofilters or biotrickling filters. Gosse et al. [90] demonstrated intensified absorption or evolution of $\mathrm{H}_{2}, \mathrm{CO}$, $\mathrm{CO}_{2}$ or $\mathrm{O}_{2}$ from biocoatings on paper located above the liquid phase. The microbes used were Chlamydomonas reinhardtii CC124 (eukaryotic microalgae phototroph being engineered for renewable energy applications); Rhodopseudomonas palustris CGA009 (anaerobic bacterial phototroph), which produces $\mathrm{H}_{2}$ gas; Clostridium ljungdahlii OTA1 (anaerobic autotrophic acetogenic ethanologen), for conversion of syngas to ethanol; and the Synechococcus sp. PCC7002 (cyanobacterial aerobic phototroph). Investigation of $C$. ljungdahlii biocoated papers, coated without adhesive latex, has recently be extended by Schulte et al. [91], who optimized surface area, with mass-transfer power input reduced by 3 orders of magnitude compared to traditional bioreactors and reduced liquid volume. His approach intensified the rate of $\mathrm{CO}$ uptake by over 17 fold. These studies demonstrate new designs for engineering reactive biofilters that absorb gases $\left(\mathrm{CO}, \mathrm{CO}_{2}, \mathrm{CH}_{4}, \mathrm{H}_{2}, \mathrm{NO}_{\mathrm{x}}, \mathrm{SO}_{\mathrm{x}}\right)$ or produce useful gases $\left(\mathrm{O}_{2}, \mathrm{H}_{2}, \mathrm{CH}_{4}\right)$ for low-power-input largescale gas processing [100-102]. This is leading to investigation of biocoatings in thin-film, falling film or spinning disk bioreactors, and rotating biological contactors (RBCs) for large-scale gas absorption with significantly reduced power input for mass transfer [12,13,100-104].

The possibility is emerging to exploit high intensity biocoatings for wastewater treatment involving complex microbial consortia. One example is significantly increasing the rate of the nitrificationdenitrification [105]. The conversion of organic nitrogen to gaseous nitrogen involves a strict and balanced cooperation of three microorganisms, two of which are nitrifiers (Nitrosomonas europaea and Nitrobacter vulgaris) and the last one a denitrifier (Paracoccus denitrificans). Nitrifying bacteria are slow-growing, oxygen dependents and very sensitive microorganisms when compared with denitrifiers (oxygen sensitive microorganisms). The development of an artificial consortium using three adjacent adhesive nanoporous layers of highly concentrated bacteria containing in each layer a single species providing the substrate for the adjacent layer has all the characteristics of becoming a groundbreaking environmental remediation technology (Fig. 5). In this process, an 

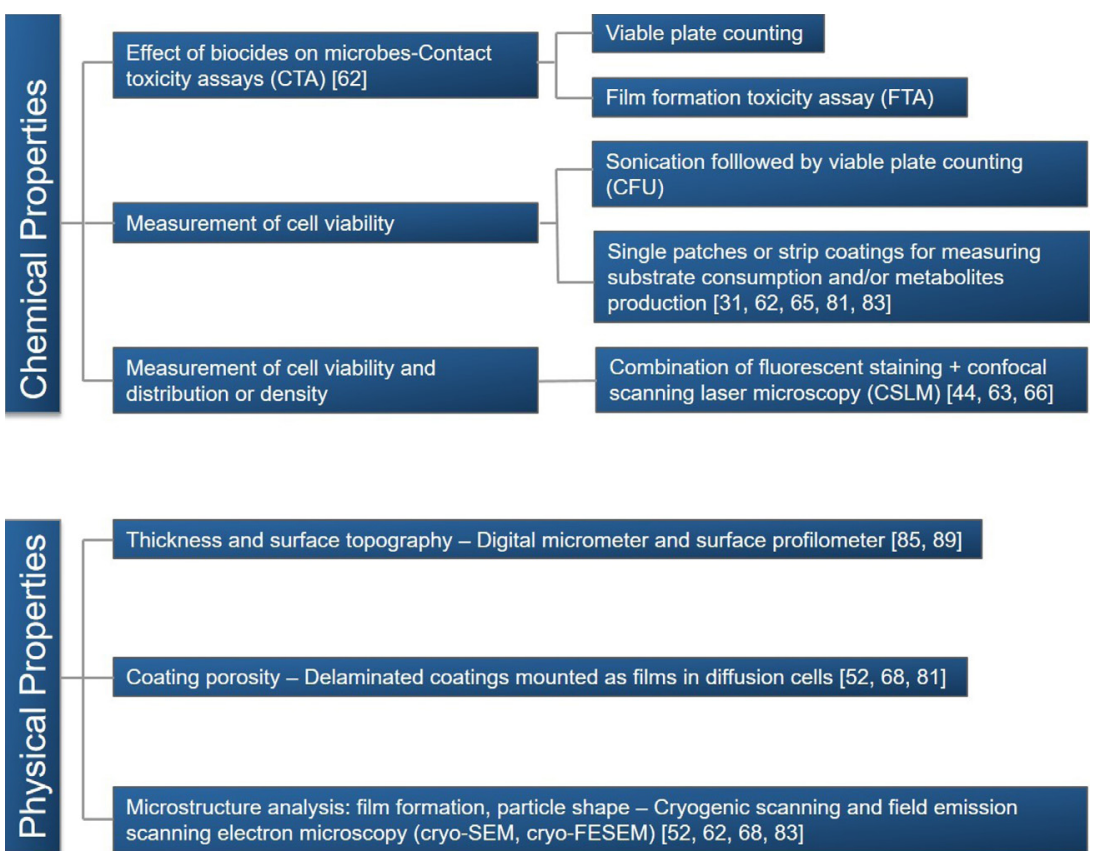

Fig. 3. Methods for biocoating characterization.
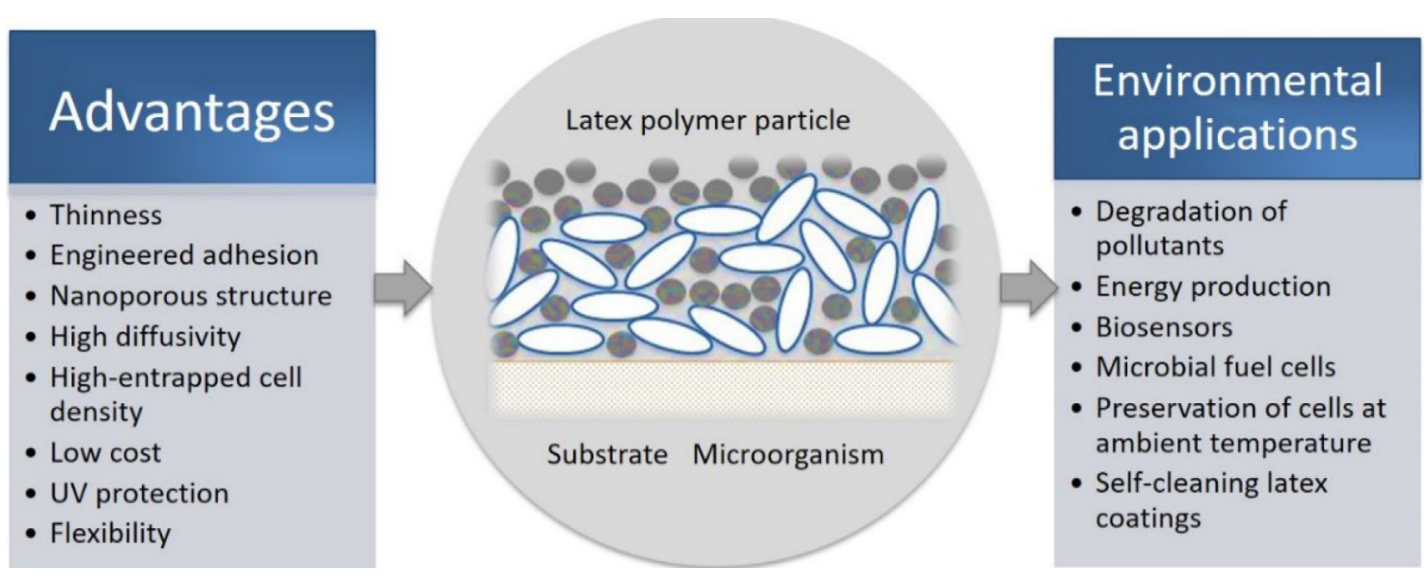

Fig. 4. Advantages and environmental applications of immobilized cells in biocoatings.

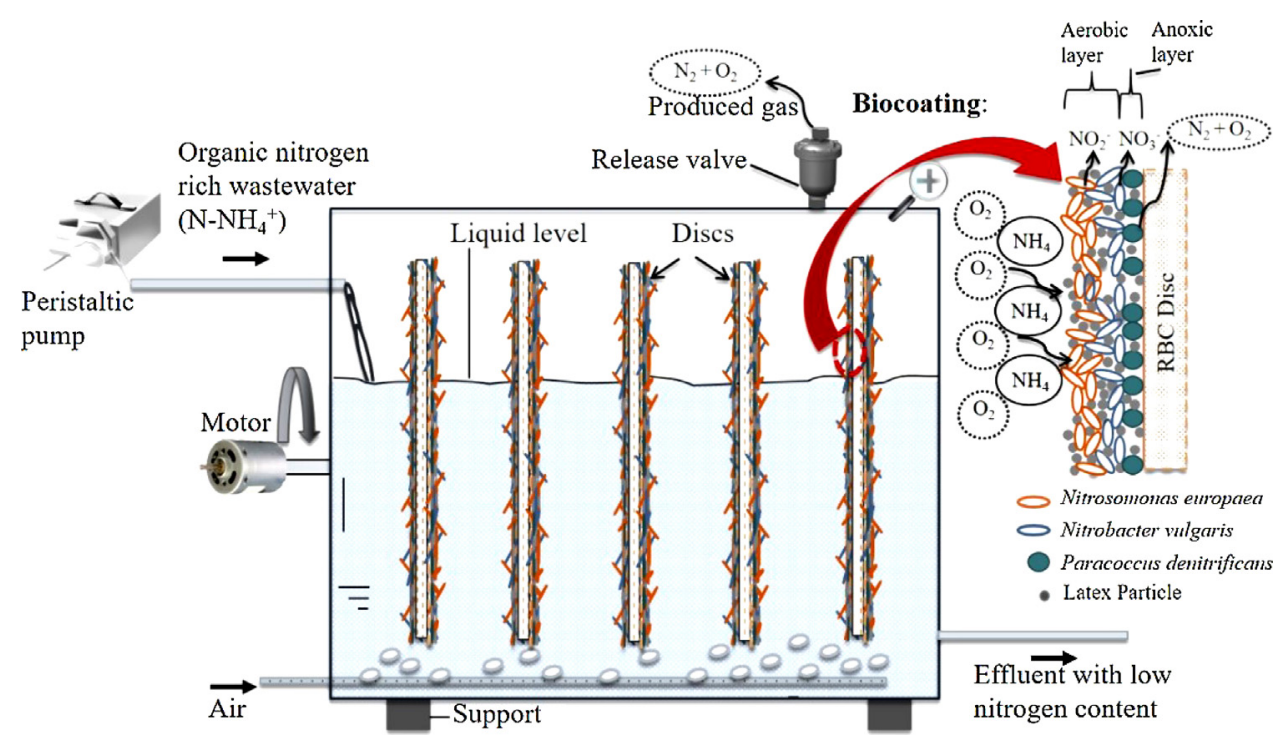

Fig. 5. Scheme of application of biocoatings in a rotating biological contactors (RBC) reactor for wastewater treatment using different microorganisms. 
ammonium-oxidizing organism (Nitrosomonas europaea) converts ammonium $\left(\mathrm{N}-\mathrm{NH}_{4}{ }^{+}\right)$into nitrite $\left(\mathrm{N}^{-\mathrm{NO}_{2}}{ }^{-}\right)$, then a nitrite dissimilatory organism (Nitrobacter vulgaris) oxidizes nitrite into nitrate $\left(\mathrm{N}-\mathrm{NO}_{3}{ }^{-}\right)$and finally a denitrifier (Paracoccus denitrificans) converts nitrate into nitrogen gas $\left(\mathrm{N}_{2}\right)$.

A recent approach to improve solar energy harvesting by combining complementary photosynthetic microbes is to fabricate biocoatings that mimic the function and stability of natural plant leaves by ordering layers of closely packed photosynthetic cells on a surface with non-toxic adhesive polymer binders. Bernal et al. [34] investigated this concept with a porous paper nonwoven substrate for supporting latex coatings of cyanobacteria above a liquid phase to function as biosolar absorbers (or biomimetic leaves), absorbing $\mathrm{CO}_{2}$ and producing $\mathrm{O}_{2}$. Four different cyanobacteria strains (Synechococcus PCC7002, Synechocystis PCC6803, Synechocystis PCC6308, and Anabaena PCC7120) with diverse morphologies were used, and it was demonstrated that this simple method of latex binder coating by extrusion is capable of intensifying 5-10-fold the specific photoreactivity of suspended cyanobacteria in non-growth nitrogen-limited media [34]. Since neither the cyanobacteria strains nor the biocomposite paper microstructure were optimized, this level of biocoating photoreactivity is remarkable.

Rapid and selective biocoating film as biosensors able to detect pollutants at very low levels could enhance our understanding and protect the environment [106]. Biocoating sensors are receiving growing attention for measuring toxic gases and toxic soluble compounds in water and wastewater. Lyngberg et al. [70] developed a single-use luciferase-based mercury biosensor using Escherichia coli HB101 in a latex copolymer film. The immobilized E. coli HB101 cells harbored a mer-lux plasmid construct and produced a detectable light signal when exposed to $\mathrm{Hg}(\mathrm{II})$. This cell $\mathrm{Hg}(\mathrm{II})$ biosensor had a sensitivity similar to that of suspended cells but a significantly larger detection range. The levels of mercury detected ranged from $0.1 \mathrm{nM}$ to $10000 \mathrm{nM} \mathrm{HgCl}_{2}$.

The fabrication of thin $(<10 \mu \mathrm{m}$ thick), robust biocoatings for biosensors may be an important approach to overcome the slow reactivity of whole cell biosensors [106]. In order to generate these thin coatings, biocoating formulations have been developed as fast drying microbial inks for 3-D printing of uniform coatings, ink-jet microstructures or as sensing components of bioelectronics devices [67]. Fidaleo et al. [94] demonstrated that ink-jet droplet deposition of Gluconobacter oxidans can be controlled to precisely deliver droplets onto flexible polyester to create nanoporous microstructures with defined height, uniform surfaces and large surface area without cell death during ink deposition and controlled drying. G. oxidans is a useful model biosensor organism for detecting alcohols, carbohydrates and polyols. Cell densities of up to $10^{14} \mathrm{~m}^{-2}$ could be achieved with 3-D printed microstructures with 5:1 height to diameter ratio. This ink-jet technique indicates the potential for rapid fabrication of high surface area 3-D printed whole cell biosensor arrays on flexible microelectronic or microfluidic devices using adhesive latex binders.

Biocoatings may also be applied in energy production and storage to transfer electrons to conductive surfaces in microbial fuel cells [40]. Recently, Wagner et al. [92] proposed a proof-of-concept immobilization approach that allows exoelectrogenic activity of cells on an electrode consisting of a layer of latex holding bacteria on surfaces. A single topcoat layer of airbrushcoating did not reduce the voltage produced by a biofilm in a microbial fuel cell (MFC), and the more easily applied dip-and-blot coating reduced voltage by only $11 \%$ in a microbial electrolysis cell (MEC). Dry-stabilized biocoating entrapped cells may be stabilized "ready-to-use reagents" that can be stored for prolonged time under controlled conditions of moisture and, once activated, (e.g., by hydration, a temperature change or addition of nutrients), generate a reproducible number of reactive cells for sensing [21].
Biocoating stability and storage are important design parameters [21]. Lyngberg et al. [87] noticed that thin bimodal blend coatings of acrylate/vinyl acetate latex are useful to concentrate and stabilize metabolically active Thermotoga maritima, an hyperthermophile, in artificial sea water (ASW). These coatings preserved high amylase activity for $100 \mathrm{~s}$ of hours at $80^{\circ} \mathrm{C}$ in ASW. Fidaleo et al. [93] demonstrated that a strictly aerobic acetic acid bacterium Gluconobacter oxydans - could be preserved at ambient temperature, concentrated, entrapped, and retained in thin nanoporous multi-layer coatings under nitrogen-limited conditions and following rehydration, carry out an oxygen-requiring sugar bioconversion at high efficiency and intensity. Similarly, Piskorska et al. [71] observed that when stored in argon at $<5 \%$ humidity and room temperature, $R$. palustris biocoatings retained full $\mathrm{H}_{2}$ production activity for 3 months.

\section{Biocoatings: future perspectives}

The cooperation between nanoscience, nanomaterials, waterborne coating technology, synthetic biology/biotechnology and microalgae scientists and engineers is resulting in emerging technologies to fabricate innovative functional biological nanosystems containing stabilized living cells. In particular, the controlled exploration of engineered whole cells in biocoatings seems to be very promising for low cost biochemical transformation of waste waters and waste gases with enhanced intensity (small footprint) and efficiency.

The vast potential of using engineered immobilized photosynthetic cells, where better illumination efficiencies, higher photoreactivity and long-term stability can be obtained when cells are coated into thin structured layers, has been demonstrated. Since algae, plant cells and cyanobacteria are highly promising as energy converters, biocoating research should focus on these organisms. Indeed, photoreactivity superior to natural leaves may be possible if photosaturation can be minimized by spatially isolating and optimizing cells with altered photopigment content, alter microstructure to control illumination intensity, and engineer coating microstructures with altered reflectance and light scattering properties.

The multiple capabilities of immobilized whole cells in biocoatings as environmental biosensors and large scale biocatalysts has not been fully explored. By investigating a combination of how different biosensing cells, miniaturized transducers and detection techniques could be incorporated in advanced polymer materials or microfluidic devices revolutionary new biosensing composite materials could be fabricated. Indeed, the exploration of solar energy harvesting through the utilization of biocoatings of nongrowing cyanobacteria, algae and plant cells, coupled with suitable electrodes, could provide an ideal way to produce clean energy and recycle $\mathrm{CO}_{2}$ into chemicals and liquid fuels with minimal water use.

Unfortunately, the biology of non-growing microorganisms is poorly understood. By devising how to manipulate the regulation of gene expression without growth, the specific reactivity of biocoatings could be significantly increased. Furthermore, mastering the regulation of in vivo message stability and proteolysis in nongrowing microbes may lead to strategies to alter protein expression and protease activity in biocoatings and to design enzymes with very long in vivo functional half-lives.

Understanding the desiccation tolerance in anhydrobiotes organisms will enable us to induce or engineer tolerance in desiccation sensitive microbes, and devise strategies to enhance long-term stabilization and preservation of many types of cells and biological materials in a dry state in biocoatings.

There is an increasing interest in the application of biocoating processes industrially. However, the translation of this laboratory 
concept into large-scale waste treatment processes is currently frustrated until an application with a sufficient market to support the development of a biocoating fabrication process is identified. It will be extremely interesting to see how new, more efficient thin film bioreactor configurations such as RBCs or spinning disc bioreactors could accelerate industrial acceptance of biocoatings. Moreover, biocoatings consisting of multiple species should also be considered.

\section{Acknowledgements}

This study was supported by the Portuguese Foundation for Science and Technology (FCT) under the scope of the strategic funding of UID/BIO/04469/2013 unit and COMPETE 2020 (POCI-01-0145-FEDER-006684) and BioTecNorte operation (NORTE-01-0145-FEDER-000004) funded by European Regional Development Fund under the scope of Norte2020 - Programa Operacional Regional do Norte. Susana Cortez acknowledges the FCT individual grant SFRH/BPD/73720/2010.

\section{References}

[1] G.M. Whitesides, The right size in nanobiotechnology, Nat. Biotechnol. 21 (2003) 1161-1165, http://dx.doi.org/10.1038/nbt872.

[2] P. Kaul, Y. Asano, Strategies for discovery and improvement of enzyme function: state of the art and opportunities, Microb. Biotechnol. 5 (2012) 18-33, http://dx.doi.org/10.1111/j.1751-7915.2011.00280.x.

[3] S.M. Thomas, R. DiCosimo, V. Nagarajan, Biocatalysis: applications and potentials for the chemical industry, Trends Biotechnol. 20 (2002) 238-242, http://dx.doi.org/10.1016/S0167-7799(02)01935-2.

[4] B.H. Davison, J.W. Barton, G.R. Petersen, Nomenclature and methodology for classification of nontraditional biocatalysis, Biotechnol. Prog. 13 (1997) 512-518, http://dx.doi.org/10.1021/bp9700891.

[5] A. Léonard, P. Dandoy, E. Danloy, G. Leroux, C.F. Meunier, J.C. Rooke, B.-L. Su, Whole-cell based hybrid materials for green energy production, environmental remediation and smart cell-therapy, Chem. Soc. Rev. 40 (2011) 860-885, http://dx.doi.org/10.1039/C0CS00024H.

[6] P. Tufvesson, W. Fu, J.S. Jensen, J.M. Woodley, Process considerations for the scale-up and implementation of biocatalysis, Food Bioprod. Process. 88 (2010) 3-11, http://dx.doi.org/10.1016/j.fbp.2010.01.003.

[7] H. Fukuda, A. Kondo, S. Tamalampudi, Bioenergy: sustainable fuels from biomass by yeast and fungal whole-cell biocatalysts, Biochem. Eng. J. 44 (2009) 2-12, http://dx.doi.org/10.1016/j.bej.2008.11.016.

[8] C.F. Meunier, X.-Y. Yang, J.C. Rooke, B.-L. Su, Biofuel cells based on the immobilization of photosynthetically active bioentities, ChemCatChem 3 (2011) 476-488, http://dx.doi.org/10.1002/cctc.201000410.

[9] B. Halan, K. Buehler, A. Schmid, Biofilms as living catalysts in continuous chemical syntheses, Trends Biotechnol. 30 (2012) 453-465, http://dx.doi. org/10.1016/j.tibtech.2012.05.003.

[10] C.F. Meunier, P. Dandoy, B.-L. Su, Encapsulation of cells within silica matrixes: towards a new advance in the conception of living hybrid materials, J. Colloid Interface Sci. 342 (2010) 211-224, http://dx.doi.org/10. 1016/j.jcis.2009.10.050.

[11] S. Pugh, R. McKenna, R. Moolick, D.R. Nielsen, Advances and opportunities at the interface between microbial bioenergy and nanotechnology, Can. J. Chem. Eng. 89 (2011) 2-12, http://dx.doi.org/10.1002/cjce.20434.

[12] J.S. Jenkins, M.C. Flickinger, O.D. Velev, Engineering cellular photocomposite materials using convective assembly, Materials 6 (2013) 1803-1825, http: / dx.doi.org/10.3390/ma6051803.

[13] J.L. Gosse, B.J. Engel, J.C.-H. Hui, C.S. Harwood, M.C. Flickinger, Progress toward a biomimetic leaf: 4000 -h of hydrogen production by coating-stabilized nongrowing photosynthetic Rhodopseudomonas palustris, Biotechnol. Prog. 26 (2010) 907-918, http://dx.doi.org/10.1002/ btpr.406.

[14] M. Schrewe, M.K. Julsing, B. Bühler, A. Schmid, Whole-cell biocatalysis for selective and productive $\mathrm{CO}$ functional group introduction and modification, Chem. Soc. Rev. 42 (2013) 6346-6377, http://dx.doi.org/10.1039/ C3CS60011D.

[15] J.B. McKinlay, Y. Oda, M. Rühl, A.L. Posto, U. Sauer, C.S. Harwood, Non-growing Rhodopseudomonas palustris increases the hydrogen gas yield from acetate by shifting from the glyoxylate shunt to the tricarboxylic acid cycle, J. Biol. Chem. 289 (2014) 1960-1970, http://dx.doi.org/10.1074/jbc. M113.527515.

[16] M.W. Ullah, W.A. Khattak, M. Ul-Islam, S. Khan, J.K. Park, Bio-ethanol production through simultaneous saccharification and fermentation using an encapsulated reconstituted cell-free enzyme system, Biochem. Eng. J. 91 (2014) 110-119, http://dx.doi.org/10.1016/j.bej.2014.08.006.

[17] M.W. Ullah, W.A. Khattak, M. Ul-Islam, S. Khan, J.K. Park, Metabolic engineering of synthetic cell-free systems: strategies and applications,
Biochem. Eng. J. 105 (Part B) (2016) 391-405, http://dx.doi.org/10.1016/j. bej.2015.10.023.

[18] E. Gultepe, D. Nagesha, L. Menon, A. Busnaina, S. Sridhar, High-throughput assembly of nanoelements in nanoporous alumina templates, Appl. Phys. Lett. 90 (2007), http://dx.doi.org/10.1063/1.2730575, 163119-163119-3.

[19] J. Kim, J.W. Grate, P. Wang, Nanobiocatalysis and its potential applications, Trends Biotechnol. 26 (2008) 639-646, http://dx.doi.org/10.1016/j.tibtech. 2008.07.009.

[20] C. Xu, X. Qu, Cerium oxide nanoparticle: a remarkably versatile rare earth nanomaterial for biological applications, NPG Asia Mater. 6 (2014) e90, http://dx.doi.org/10.1038/am.2013.88.

[21] E. Michelini, A. Roda, Staying alive: new perspectives on cell immobilization for biosensing purposes, Anal. Bioanal. Chem. 402 (2012) 1785-1797, http:// dx.doi.org/10.1007/s00216-011-5364-x.

[22] O.M. Zacheus, E.K. Iivanainen, T.K. Nissinen, M.J. Lehtola, P.J. Martikainen, Bacterial biofilm formation on polyvinyl chloride, polyethylene and stainless steel exposed to ozonated water, Water Res. 34 (2000) 63-70, http://dx.doi.org/10.1016/S0043-1354(99)00113-X.

[23] T. An, L. Zhou, G. Li, J. Fu, G. Sheng, Recent patents on immobilized microorganism technology and its engineering application in wastewater treatment, Recent Pat. Eng. 2 (2008) 28-35, http://dx.doi.org/10.2174/ 187221208783478543.

[24] A. Sinsawat, K.L. Anderson, R.A. Vaia, B.L. Farmer, Influence of polymer matrix composition and architecture on polymer nanocomposite formation: coarse-grained molecular dynamics simulation, J. Polym. Sci. Part B Polym. Phys. 41 (2003) 3272-3284, http://dx.doi.org/10.1002/polb.10696.

[25] A. Roda, B. Roda, L. Cevenini, E. Michelini, L. Mezzanotte, P. Reschiglian, K. Hakkila, M. Virta, Analytical strategies for improving the robustness and reproducibility of bioluminescent microbial bioreporters, Anal. Bioanal. Chem. 401 (2011) 201-211, http://dx.doi.org/10.1007/s00216-011-5091-3.

[26] J. Wang, P. Liu, Y. Qian, Biodegradation of phthalic acid esters by immobilized microbial cells, Environ. Int. 23 (1997) 775-782, http://dx.doi. org/10.1016/S0160-4120(97)00089-5.

[27] N. Akhtar, J. Iqbal, M. Iqbal, Removal and recovery of nickel(II) from aqueous solution by loofa sponge-immobilized biomass of Chlorella sorokiniana: characterization studies, J. Hazard. Mater. 108 (2004) 85-94, http://dx.doi. org/10.1016/j.jhazmat.2004.01.002.

[28] N. Rangsayatorn, P. Pokethitiyook, E.S. Upatham, G.R. Lanza, Cadmium biosorption by cells of Spirulina platensis TISTR 8217 immobilized in alginate and silica gel, Environ. Int. 30 (2004) 57-63, http://dx.doi.org/10.1016/ S0160-4120(03)00146-6.

[29] E. Reátegui, E. Reynolds, L. Kasinkas, A. Aggarwal, M.J. Sadowsky, A. Aksan, L.P. Wackett, Silica gel-encapsulated AtzA biocatalyst for atrazine biodegradation, Appl. Microbiol. Biotechnol. 96 (2012) 231-240, http://dx. doi.org/10.1007/s00253-011-3821-2.

[30] M.G.M. Purwanto, M.V. Maretha, M. Wahyudi, M.T. Goeltom, Whole cell hydrolysis of sardine (Sardinella Lemuru) oil waste using Mucor Circinelloides NRRL 1405 immobilized in poly-urethane foam, Procedia Chem. 14 (2015) 256-262, http://dx.doi.org/10.1016/j.proche.2015.03.036.

[31] J. Raff, U. Soltmann, S. Matys, S. Selenska-Pobell, H. Böttcher, W. Pompe, Biosorption of uranium and copper by biocers, Chem. Mater. 15 (2003) 240-244, http://dx.doi.org/10.1021/cm0212131.

[32] D. Fiedler, A. Thron, U. Soltmann, H. Böttcher, New packing materials for bioreactors based on coated and fiber-reinforced biocers, Chem. Mater. 16 (2004) 3040-3044, http://dx.doi.org/10.1021/cm040156o.

[33] J.L. Gosse, B.J. Engel, F.E. Rey, C.S. Harwood, L.E. Scriven, M.C. Flickinger, Hydrogen production by photoreactive nanoporous latex coatings of nongrowing Rhodopseudomonas palustris CGA009, Biotechnol. Prog. 23 (2007) 124-130, http://dx.doi.org/10.1021/bp060254.

[34] O.I. Bernal, C.B. Mooney, M.C. Flickinger, Specific photosynthetic rate enhancement by cyanobacteria coated onto paper enables engineering of highly reactive cellular biocomposite leaves, Biotechnol. Bioeng. 111 (2014) 1993-2008, http://dx.doi.org/10.1002/bit.25280.

[35] D. Surendhiran, M. Vijay, A.R. Sirajunnisa, Biodiesel production from marine microalga Chlorella salina using whole cell yeast immobilized on sugarcane bagasse, J. Environ. Chem. Eng. 2 (2014) 1294-1300, http://dx.doi.org/10 1016/j.jece.2014.05.004.

[36] C.S. Kim, B.-H. Choi, J.H. Seo, G. Lim, H.J. Cha, Mussel adhesive protein-based whole cell array biosensor for detection of organophosphorus compounds, Biosens. Bioelectron. 41 (2013) 199-204, http://dx.doi.org/10.1016/j.bios. 2012.08.022.

[37] X. Qiao, Z. Liu, Z. Liu, Y. Zeng, Z. Zhang, Optimized immobilization of activated sludge in poly(ethylene glycol) gels by UV technology, Process Biochem. 45 (2010) 1342-1347, http://dx.doi.org/10.1016/j.procbio.2010. 05.003.

[38] S. Athalye, R. Sharma-Shivappa, S. Peretti, P. Kolar, J.P. Davis, Producing biodiesel from cottonseed oil using Rhizopus oryzae ATCC \#34612 whole cell biocatalysts: culture media and cultivation period optimization, Energy Sustain. Dev. 17 (2013) 331-336, http://dx.doi.org/10.1016/j.esd.2013.03. 009.

[39] J. Ha, C.R. Engler, J.R. Wild, Biodegradation of coumaphos, chlorferon, and diethylthiophosphate using bacteria immobilized in Ca-alginate gel beads, Bioresour. Technol. 100 (2009) 1138-1142, http://dx.doi.org/10.1016/j biortech.2008.08.022.

[40] S. Srikanth, E. Marsili, M.C. Flickinger, D.R. Bond, Electrochemical characterization of Geobacter sulfurreducens cells immobilized on graphite 
paper electrodes, Biotechnol. Bioeng. 99 (2008) 1065-1073, http://dx.doi. org/10.1002/bit.21671.

[41] M. Hucík, M. Bučko, P. Gemeiner, V. Štefuca, A. Vikartovská, M.D. Mihovilovič, F. Rudroff, N. Iqbal, D.C. Jr, I. Lacík, Encapsulation of recombinant $E$. coli expressing cyclopentanone monooxygenase in polyelectrolyte complex capsules for Baeyer-Villiger biooxidation of 8-oxabicyclo[3.2.1]oct-6-en-3-one, Biotechnol. Lett. 32 (2010) 675-680, http://dx.doi.org/10.1007/s10529-010-0203-2.

[42] A. Guldhe, P. Singh, S. Kumari, I. Rawat, K. Permaul, F. Bux, Biodiesel synthesis from microalgae using immobilized Aspergillus niger whole cell lipase biocatalyst, Renew. Energy 85 (2016) 1002-1010, http://dx.doi.org/ 10.1016/j.renene.2015.07.059.

[43] G. Chen, J. Liu, Y. Qi, J. Yao, B. Yan, Biodiesel production using magnetic whole-cell biocatalysts by immobilization of Pseudomonas mendocina on Fe304-chitosan microspheres, Biochem. Eng. J. 113 (2016) 86-92, http://dx. doi.org/10.1016/j.bej.2016.06.003.

[44] C. Lin, L. Gan, Z. Chen, M. Megharaj, R. Naidu, Biodegradation of naphthalene using a functional biomaterial based on immobilized Bacillus fusiformis (BFN), Biochem. Eng. J. 90 (2014) 1-7, http://dx.doi.org/10.1016/j.bej.2014. 05.003 .

[45] H. Xie, H. Liu, Y. Xie, M. Yang, S. Guo, Z. Zhou, H. Xu, Fabrication of a novel immobilization system and its application for removal of anthracene from soil, Biochem. Eng. J. 97 (2015) 8-16, http://dx.doi.org/10.1016/j.bej.2015. 01.011.

[46] M.S. Mauter, M. Elimelech, Environmental applications of carbon-based nanomaterials, Environ. Sci. Technol. 42 (2008) 5843-5859.

[47] J.S. Jenkins, M.C. Flickinger, O.D. Velev, Deposition of composite coatings from particle-particle and particle-yeast blends by convective-sedimentation assembly, J. Colloid Interface Sci. 380 (2012) 192-200, http://dx.doi.org/10.1016/j.jcis.2012.04.060.

[48] D. Avnir, T. Coradin, O. Lev, J. Livage, Recent bio-applications of sol-gel materials, J. Mater. Chem. 16 (2006) 1013-1030, http://dx.doi.org/10.1039/ B512706H.

[49] V.B. Kandimalla, V.S. Tripathi, H. Ju, Immobilization of biomolecules in sol-gels: biological and analytical applications, Crit. Rev. Anal. Chem. 36 (2006) 73-106, http://dx.doi.org/10.1080/10408340600713652.

[50] K.K. Flora, J.D. Brennan, Effect of matrix aging on the behavior of human serum albumin entrapped in a tetraethyl orthosilicate-derived glass, Chem. Mater. 13 (2001) 4170-4179, http://dx.doi.org/10.1021/cm0101551.

[51] J. Rajan Premkumar, S. Belkin, O. Lev, Sol-gel luminescence biosensors: encapsulation of recombinant $E$. coli reporters in thick silicate films, Anal. Chim. Acta 462 (2002) 11-23, http://dx.doi.org/10.1016/S00032670(02)00301-X.

[52] R. Gupta, N.K. Chaudhury, Entrapment of biomolecules in sol-gel matrix for applications in biosensors: problems and future prospects, Biosens. Bioelectron. 22 (2007) 2387-2399, http://dx.doi.org/10.1016/j.bios.2006.12. 025.

[53] R.E. Ionescu, C. Gondran, S. Cosnier, L.A. Gheber, R.S. Marks, Comparison between the performances of amperometric immunosensors for cholera antitoxin based on three enzyme markers, Talanta 66 (2005) 15-20, http:// dx.doi.org/10.1016/j.talanta.2004.06.048.

[54] J. Jia, M. Tang, X. Chen, L. Qi, S. Dong, Co-immobilized microbial biosensor for BOD estimation based on sol-gel derived composite material, Biosens. Bioelectron. 18 (2003) 1023-1029, http://dx.doi.org/10.1016/s09565663(02)00225-7.

[55] G. Lear, Molecular methods for the assessment of microbial biofilms in bioremediation, in: Biofilms Bioremediation Curr. Res. Emerg. Technol, Caister Academic Press, The University of Auckland, New Zealand, 2016 http://www.horizonpress.com/biorem.

[56] B. Rosche, X.Z. Li, B. Hauer, A. Schmid, K. Buehler, Microbial biofilms: a concept for industrial catalysis? Trends Biotechnol. 27 (2009) 636-643, http://dx.doi.org/10.1016/j.tibtech.2009.08.001.

[57] O.K. Lyngberg, C.P. Ng, V. Thiagarajan, L.E. Scriven, M.C. Flickinger, Engineering the microstructure and permeability of thin multilayer latex biocatalytic coatings containing E.coli, Biotechnol. Prog. 17 (2001) 1169-1179, http://dx.doi.org/10.1021/bp0100979.

[58] R.P. Dias, J.A. Teixeira, M.G. Mota, A.I. Yelshin, Particulate binary mixtures: Dependence of packing porosity on particle size ratio, Ind. Eng. Chem. Res. 43 (2004) 7912-7919, http://dx.doi.org/10.1021/ie040048b.

[59] M. Mota, J. Teixeira, A. Yelshin, Image analysis of packed beds of spherical particles of different sizes, Sep. Purif. Technol. 15 (1999) 59-68, http://dx. doi.org/10.1016/S1383-5866(98)00085-9.

[60] M. Mota, J.A. Teixeira, W.R. Bowen, A. Yelshin, Binary spherical particle mixed beds: porosity and permeability relationship measurement, Trans. Filtr. Soc. 1 (2001) 101-106.

[61] O.K. Lyngberg, Development of Thin Biocatalytic Composite Coatings Consisting of Latex and Metabolically Active Bacterial Cells, Ph. D. Thesis, University of Minnesota, 2000.

[62] H.E. Lawton, H.E. Klei, D.W. Sundstrom, P.J. Voronka, C.D. Scott, Immobilization of whole cells using polymeric coatings, in: Proc. 8th Symp. Biotechnol. Fuels Chem., Gatlinburg, Tennessee, 1986.

[63] W.P. Flanagan, H.E. Klei, D.W. Sundstrom, C.W. Lawton, Optimization of a pellicular biocatalyst for penicillin $G$ production by Penicillium chrysogenum, Biotechnol. Bioeng. 36 (1990) 608-616, http://dx.doi.org/10.1002/bit. 260360608.
[64] T.J. Bunning, C.W. Lawton, H.E. Klei, D.W. Sundstrom, Physical property improvements of a pellicular biocatalyst, Bioprocess. Eng. 7 (1991) 71-75, http://dx.doi.org/10.1007/BF00383581.

[65] J.B. Cantwell, P.D.A. Mills, E. Jones, R.F. Stewart, Immobilised Cells, EP0288203 B1, 1995, Accessed December 5, 2014 http://www.google.com/ patents/EP0288203B1.

[66] N. Martens, E.A.H. Hall, Immobilisation of photosynthetic cells based on film-forming emulsion polymers, Anal. Chim. Acta 292 (1994) 49-63, http:// dx.doi.org/10.1016/0003-2670(94)00038-7.

[67] M.C. Flickinger, J.L. Schottel, D.R. Bond, A. Aksan, L.E. Scriven, Painting and printing living bacteria: engineering nanoporous biocatalytic coatings to preserve microbial viability and intensify reactivity, Biotechnol. Prog. 23 (2007) 2-17, http://dx.doi.org/10.1021/bp060347r.

[68] K.L. Swope, M.C. Flickinger, The use of confocal scanning laser microscopy and other tools to characterize Escherichia coli in a high-cell-density synthetic biofilm, Biotechnol. Bioeng. 52 (1996) 340-356, http://dx.doi.org/ 10.1002/(SICI)1097-0290(19961020)52:2<340:AID-BIT14>3.0.CO;2-N.

[69] M. Mota, A. Yelshin, M. Fidaleo, M.C. Flickinger, Modelling diffusivity in porous polymeric membranes with an intermediate layer containing microbial cells, Biochem. Eng. J. 37 (2007) 285-293, http://dx.doi.org/10. 1016/j.bej.2007.05.008.

[70] O.K. Lyngberg, D.J. Stemke, J.L. Schottel, M.C. Flickinger, A single-use luciferase-based mercury biosensor using Escherichia coli HB101 immobilized in a latex copolymer film, J. Ind. Microbiol. Biotechnol. 23 (1999) 668-676, http://dx.doi.org/10.1038/sj.jim.2900679.

[71] M. Piskorska, T. Soule, J.L. Gosse, C. Milliken, M.C. Flickinger, G.W. Smith, C.M. Yeager, Preservation of $\mathrm{H}_{2}$ production activity in nanoporous latex coatings of Rhodopseudomonas palustris CGA009 during dry storage at ambient temperatures, Microb. Biotechnol. 6 (2013) 515-525, http://dx.doi. org/10.1111/1751-7915.12032.

[72] A. Guy, The science and art of paint formulation, in: A.R. Marrion (Ed.), Chem. Phys. Coat., 2nd ed., Royal Society of Chemistry, Cambridge, 2004, pp. 317-346, Accessed December 5, 2014 http://pubs.rsc.org/en/content/ chapter/bk9780854046041-00317/978-0-85404-604-1.

[73] V.S. Thiagarajan, Z. Huang, L.E. Scriven, J.L. Schottel, M.C. Flickinger, Microstructure of a biocatalytic latex coating containing viable Escherichia coli cells, J. Colloid Interface Sci. 215 (1999) 244-257, http://dx. doi.org/10.1006/jcis.1999.6179.

[74] J.L. Keddie, P. Meredith, R.A.L. Jones, A.M. Donald, Film formation of acrylic latices with varying concentrations of non-Film-Forming latex particles, Langmuir 12 (1996) 3793-3801, http://dx.doi.org/10.1021/la960046z.

[75] A. Overbeek, Polymer heterogeneity in waterborne coatings, J. Coat. Technol. Res. 7 (2010) 1, http://dx.doi.org/10.1007/s11998-009-9201-5.

[76] M.C. Flickinger, O.I. Bernal, M.J. Schulte, B.J. Jenkins, C.J. Duran, A. Wallace, C.B. Mooney, O.D. Velev, Biocoatings: challenges to expanding the functionality of waterborne latex coatings by incorporating concentrated living microorganisms, J. Coat. Technol. Res. (2017) (in press).

[77] R.A. Sheldon, The e factor: fifteen years on, Green Chem. 9 (2007) 1273-1283, http://dx.doi.org/10.1039/B713736M.

[78] R.A. Sheldon, E factors, green chemistry and catalysis: an odyssey, Chem. Commun. 0 (2008) 3352-3365, http://dx.doi.org/10.1039/B803584A.

[79] P. Hillmer, H. Gest, $\mathrm{H}_{2}$ metabolism in the photosynthetic bacterium Rhodopseudomonas capsulata: production and utilization of $\mathrm{H}_{2}$ by resting cells, J. Bacteriol. 129 (1977) 732-739.

[80] M. Ishikawa, S. Yamamura, R. Ikeda, Y. Takamura, K. Sode, E. Tamiya, M. Tomiyama, Development of a compact stacked flatbed reactor with immobilized high-density bacteria for hydrogen production, Int. J. Hydrogen Energy 33 (2008) 1593-1597, http://dx.doi.org/10.1016/j.ijhydene.2007.09. 035.

[81] E. Seol, S. Kim, S.M. Raj, S. Park, Comparison of hydrogen-production capability of four different Enterobacteriaceae strains under growing and non-growing conditions, Int. J. Hydrogen Energy 33 (2008) 5169-5175, http://dx.doi.org/10.1016/j.ijhydene.2008.05.007.

[82] R.O. Schill, B. Mali, T. Dandekar, M. Schnölzer, D. Reuter, M. Frohme, Molecular mechanisms of tolerance in tardigrades: new perspectives for preservation and stabilization of biological material, Biotechnol. Adv. 27 (2009) 348-352, http://dx doi.org/10.1016/j.biotechadv.2009.01.011.

[83] S. Heux, I. Meynial-Salles, M.J. O’Donohue, C. Dumon, White biotechnology: state of the art strategies for the development of biocatalysts for biorefining, Biotechnol. Adv. 33 (2015) 1653-1670, http://dx.doi.org/10.1016/j. biotechadv.2015.08.004.

[84] N. Fu, X.D. Chen, Towards a maximal cell survival in convective thermal drying processes, Food Res. Int. 44 (2011) 1127-1149, http://dx.doi.org/10. 1016/j.foodres.2011.03.053.

[85] J.L. Keddie, Film formation of latex, Mater. Sci. Eng. R Rep. 21 (1997) 101-170, http://dx.doi.org/10.1016/S0927-796X(97)00011-9.

[86] D. Avnir, S. Braun, O. Lev, M. Ottolenghi, Enzymes and other proteins entrapped in sol-gel materials, Chem. Mater. 6 (1994) 1605-1614, http://dx. doi.org/10.1021/cm00046a008.

[87] O.K. Lyngberg, C. Solheid, S. Charaniya, Y. Ma, V. Thiagarajan, L.E. Scriven, M.C. Flickinger, Permeability and reactivity of Thermotoga maritima in latex bimodal blend coatings at $80^{\circ} \mathrm{C}$ : a model high temperature biocatalytic coating, Extremophiles 9 (2005) 197-207, http://dx.doi.org/10.1007/ s00792-005-0434-7.

[88] A. Marrion, The Chemistry and Physics of Coatings, 2nd ed., Royal Society of Chemistry, 2004, Accessed January 12, 2016 https://books.google.pt/books/ 
about/The_Chemistry_and_Physics_of_Coatings.html?hl=ptPT\&id=IZORQKOoMWUC.

[89] O.K. Lyngberg, V. Thiagarajan, D.J. Stemke, J.L. Schottel, L.E. Scriven, M.C. Flickinger, A patch coating method for preparing biocatalytic films of Escherichia coli, Biotechnol. Bioeng. 62 (1999) 44-55, http://dx.doi.org/10. 1002/(SICI)1097-0290(19990105)62:1<44:AID-BIT6>3.0.CO;2-W.

[90] J.L. Gosse, M.S. Chinn, A.M. Grunden, O.I. Bernal, J.S. Jenkins, C. Yeager, S Kosourov, M. Seibert, M.C. Flickinger, A versatile method for preparation of hydrated microbial-latex biocatalytic coatings for gas absorption and gas evolution, J. Ind. Microbiol. Biotechnol. 39 (2012) 1269-1278, http://dx.doi. org/10.1007/s10295-012-1135-8.

[91] M.J. Schulte, J. Wiltgen, J. Ritter, C.B. Mooney, M.C. Flickinger, A high gas fraction, reduced power, syngas bioprocessing method demonstrated with a Clostridium ljungdahlii OTA1 paper biocomposite, Biotechnol. Bioeng. (2016), http://dx.doi.org/10.1002/bit.25966.

[92] R.C. Wagner, S. Porter-Gill, B.E. Logan, Immobilization of anode-attached microbes in a microbial fuel cell, AMB Express 2 (2012) 2, http://dx.doi.org/ 10.1186/2191-0855-2-2.

[93] M. Fidaleo, S. Charaniya, C. Solheid, U. Diel, M. Laudon, H. Ge, L.E. Scriven, M.C. Flickinger, A model system for increasing the intensity of whole-cell biocatalysis: investigation of the rate of oxidation of D-sorbitol to L-sorbose by thin bi-layer latex coatings of non-growing Gluconobacter oxydans, Biotechnol. Bioeng. 95 (2006) 446-458, http://dx.doi.org/10.1002/bit.21051.

[94] M. Fidaleo, N. Bortone, M. Schulte, M.C. Flickinger, Ink-jet printing of Gluconobacter oxydans: micropatterned coatings as high surface-to-volume ratio bio-reactive, Coatings 4 (2014) 1-17, http://dx.doi.org/10.3390/ coatings4010001.

[95] J.S. Jenkins, M.C. Flickinger, O.D. Velev, Continuous convective-sedimentation assembly of colloidal microsphere coatings for biotechnology applications, Coatings 3 (2013) 26-48, http://dx.doi.org/10. 3390/coatings3010026.

[96] O. Bernal, Mimicking the Plant Leaf: Cellular Composite Materials for Capturing Solar Energy and Gas-phase Biocatalysis, Ph. D. Thesis, North Carolina State University, 2014 http://repository.lib.ncsu.edu/ir/bitstream/ 1840.16/10441/1/etd.pdf.
[97] P. Kumnorkaew, Y.-K. Ee, N. Tansu, J.F. Gilchrist, Investigation of the deposition of microsphere monolayers for fabrication of microlens arrays, Langmuir 24 (2008) 12150-12157, http://dx.doi.org/10.1021/la801100g.

[98] B.G. Prevo, O.D. Velev, Controlled, rapid deposition of structured coatings from micro- and nanoparticle suspensions, Langmuir 20 (2004) 2099-2107, http://dx.doi.org/10.1021/la035295j.

[99] J.M. Estrada, O.I. Bernal, M.C. Flickinger, R. Muñoz, M.A. Deshusses, Biocatalytic coatings for air pollution control: a proof of concept study on VOC biodegradation, Biotechnol. Bioeng. 112 (2015) 263-271, http://dx.doi. org/10.1002/bit.25353.

[100] H.N. Abubackar, M.C. Veiga, Kennes Christian, Biological conversion of carbon monoxide: rich syngas or waste gases to bioethanol, Biofuels Bioprod. Biorefining 5 (2011) 93-114, http://dx.doi.org/10.1002/bbb.256.

[101] D.B. Levin, L. Pitt, M. Love, Biohydrogen production: prospects and limitations to practical application, Int. J. Hydrogen Energy 29 (2004) 173-185, http://dx.doi.org/10.1016/S0360-3199(03)00094-6.

[102] J. Sipma, A.M. Henstra, S.N. Parshina, P.N.L. Lens, G. Lettinga, A.J.M. Stams, Microbial CO conversions with applications in synthesis gas purification and bio-desulfurization, Crit. Rev. Biotechnol. 26 (2006) 41-65, http://dx.doi. org/10.1080/07388550500513974.

[103] J.-F. Tremblay, Japan's unique perspective, Chem. Eng. News Arch. 79 (2001) 45-49, http://dx.doi.org/10.1021/cen-v079n021.p045.

[104] S. Cortez, P. Teixeira, R. Oliveira, M. Mota, Bioreactors: rotating biological contactors, in: Encycl. Ind. Biotechnol, John Wiley \& Sons, Inc., 2013, Accessed March 7, 2013 http://onlinelibrary.wiley.com/doi/10.1002 9780470054581.eib650/abstract.

[105] F. Meng, Y. Wang, L.-N. Huang, J. Li, F. Jiang, S. Li, G.-H. Chen, A novel nonwoven hybrid bioreactor (NWHBR) for enhancing simultaneous nitrification and denitrification, Biotechnol. Bioeng. 110 (2013) 1903-1912, http://dx.doi.org/10.1002/bit.24866.

[106] X. Zhao, L. Lv, B. Pan, W. Zhang, S. Zhang, Q. Zhang, Polymer-supported nanocomposites for environmental application: a review, Chem. Eng. J. 170 (2011) 381-394, http://dx.doi.org/10.1016/j.cej.2011.02.071. 